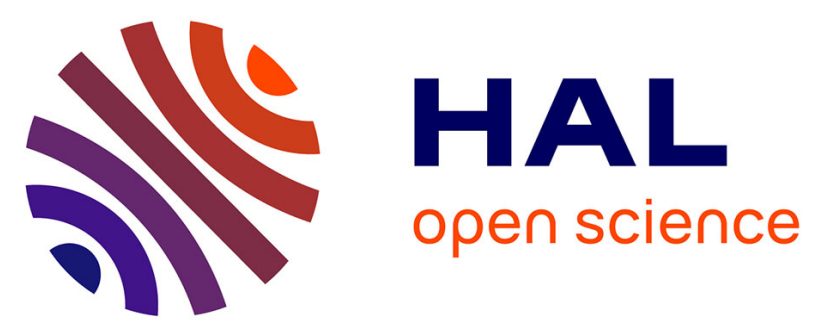

\title{
Impact of atmospheric and oceanic interannual variability on the Northwestern Mediterranean Sea pelagic planktonic ecosystem and associated carbon cycle
}

Marine Herrmann, Frederic Diaz, Claude Estournel, Patrick Marsaleix, Caroline Ulses

\section{To cite this version:}

Marine Herrmann, Frederic Diaz, Claude Estournel, Patrick Marsaleix, Caroline Ulses. Impact of atmospheric and oceanic interannual variability on the Northwestern Mediterranean Sea pelagic planktonic ecosystem and associated carbon cycle. Journal of Geophysical Research. Oceans, 2013, 118 (10), pp.5792-5813. 10.1002/jgrc.20405 . hal-02110102

\author{
HAL Id: hal-02110102 \\ https://hal.science/hal-02110102
}

Submitted on 5 Oct 2021

HAL is a multi-disciplinary open access archive for the deposit and dissemination of scientific research documents, whether they are published or not. The documents may come from teaching and research institutions in France or abroad, or from public or private research centers.
L'archive ouverte pluridisciplinaire HAL, est destinée au dépôt et à la diffusion de documents scientifiques de niveau recherche, publiés ou non, émanant des établissements d'enseignement et de recherche français ou étrangers, des laboratoires publics ou privés. 


\title{
Impact of atmospheric and oceanic interannual variability on the Northwestern Mediterranean Sea pelagic planktonic ecosystem and associated carbon cycle
}

\author{
Marine Herrmann, ${ }^{1}$ Frédéric Diaz, ${ }^{2,3}$ Claude Estournel, ${ }^{4}$ Patrick Marsaleix, ${ }^{4}$ and Caroline Ulses ${ }^{4}$
}

[1] The Northwestern Mediterranean Sea (NWMS) is one of the most productive areas of the Mediterranean Sea. The NWMS pelagic planktonic ecosystem is strongly influenced by hydrodynamics, in particular winter deep convection. Here, we investigate the response of this ecosystem and associated carbon cycle to oceanic and atmospheric winter conditions interannual variability. For that we developed a tridimensional coupled physical-biogeochemical model, ran annual simulations forced by XXth climate conditions and performed statistical and budget analysis.Our coupled model reproduces correctly the seasonal evolution of the NWMS pelagic planktonic ecosystem. It however overestimates the contribution of nanophytoplankton to the total phytoplanktonic biomass and GPP, underestimates the bacteria biomass and represents the spring bloom with 1 month delay. Our results confirm that the control of phytoplanktonic development and bacteria growth by the phosphorus availability is a marked specificity of the NWMS, that is, temporally reduced by deep convection. They confirm the relevance of the Behrenfeld (2010) hypothesis in explaining the bloom dynamics. The variability of the winter atmospheric conditions induces differences of vertical mixing and water temperature that propagate into the whole NWMS ecosystem through a chain of relationships. The high frequency filtering associated with averaging diagnostics explains that this variability seems weak at the NWMS scale. However for most of the variables and processes, differences induced by the winter atmospheric variability are significant at the annual scale. Net metabolism and deep carbon export are systematically positive and show larger variabilities related, respectively, to the water temperature and convection intensity.

\section{Introduction}

[2] The Mediterranean Sea can be considered as a scaledown model of the global ocean that enables to study at a regional scale major processes of the global oceanic circulation and water cycle [Béthoux et al., 1999]: thermohaline circulation, deep convection, dense water cascading, exchanges between the coast and the open ocean, response

\footnotetext{
${ }^{1}$ LEGOS, UMR5566, CNRS-CNES-IRD-Université de Toulouse, Toulouse, France.

${ }^{2}$ Aix-Marseille Université, CNRS/INSU, IRD, Mediterranean Institute of Oceanography (MIO), UM 110, Marseille, France.

${ }^{3}$ Université de Toulon, CNRS/INSU, IRD, Mediterranean Institute of Oceanography (MIO), UM 110, La Garde, France.

${ }^{4}$ LA, UMR5560, CNRS-OMP-Université de Toulouse, Toulouse, France.

Corresponding author: M. Herrmann, LEGOS, UMR5566, CNRSCNES-IRD-Université de Toulouse, 13 Ave. Edouard Belin, FR-31400 Toulouse CEDEX, France. (marine.herrmann@ird.fr)
}

to environmental changes. It has long been known as globally oligotrophic [Dugdale and Wilkerson, 1988; Antoine et al., 1995]. In reality it shows strong spatiotemporal gradients of nutrients and productivity largely related to different scales of hydrodynamical processes that influence the functioning of planktonic pelagic ecosystems, through their role in nutrients and plankton physical dispersion [D'Ortenzio and Ribera d'Alcalà, 2009]. This influence is particularly evident in the Northwestern Mediterranean Sea (NWMS) [Diaz et al., 2000; Niewiadomska et al., 2008], one of the most productive regions of the Mediterranean Sea [Bosc et al., 2004].

[3] Deep convection plays a major role in the NWMS [MEDOC-Group, 1970]. Winter cold and windy atmospheric events induce the deep vertical mixing of the water column, injecting nutrients abundant in the deep layers up to the depleted euphotic zone and resulting in spring blooms clearly observable through their signature on surface chlorophyll concentration [Bosc et al., 2004]. The intensity of convection is mainly related to the winter atmospheric buoyancy loss [Herrmann et al., 2010] and 
consequently shows a strong interannual variability, with "warm" years with very limited vertical mixing, and "cold" years where the water column can be mixed over its whole depth [Herrmann et al., 2009]. Given the strong influence of hydrodynamics on NWMS marine ecosystems, an important and open question is to know how these ecosystems, in particular the pelagic planktonic ecosystem that constitutes their first trophic levels, respond to the atmospheric and oceanic interannual variability.

[4] Observational studies attempted to assess the variability of Mediterranean planktonic pelagic ecosystems functioning over the late decades. These studies were however mainly dedicated to the effect of decadal variability [Kouwenberg, 1998; Marty et al., 2002; Molinero et al., 2008; Marty and Chiaverini, 2010], and very few studies dealt with interannual variability. Garcia-Comas et al. [2011] observed larger abundances of zooplankton in the Ligurian Sea in the 1980s and late 1990s after cold and dry winters characterized by strong mixing and intense spring blooms. These observations support the hypothesis of a yearly dominant bottom-up effect on the control of the zooplankton biomass and community [Vandromme et al., 2011]. A recent intercomparison of time series obtained at coastal stations showed that zooplankton fluctuations may be more due to climatic and anthropogenic local factors than related to regional climatic indexes [Berline et al., 2012]. Those results show that many studies are still required to characterize and understand the interannual to long-term variabilities of these ecosystems. Tridimensional coupled physicalbiogeochemical modeling is a relevant approach to address those questions. It is particularly suitable in the Mediterranean Sea where physical forcings and biological activity show a strong spatiotemporal variability over a large range of scales. Moreover, the numerical approach enables to grasp a part of the knowledge of the ecosystem functioning that is not accessible to observations, as biogenic element budgets at a regional scale or the succession of limiting nutrients and plankton functional types.

[5] Studies based on tridimensional coupled modeling involving plankton functional types models at the Mediterranean basin or subbasin scales remain extremely scarce. The first attempts to reproduce Mediterranean surface chlorophyll and nutrients gradients were made with either physical box models [Sarmiento et al., 1988; Béthoux et al., 1992] or more sophisticated tridimensional hydrodynamical models [Crispi et al., 1998, 1999], but these hydrodynamic models were associated with very approximate biogeochemical conceptualizations and parameterizations. Crispi et al. [2002] were the first to perform a coupling between a one-fourth degree tridimensional hydrodynamic model and a biogeochemical model based on nitrogen and phosphorus currencies and including an explicit microbial loop. They succeeded in reproducing the West-to-East gradients of chlorophyll and nutrient concentrations observed over the Mediterranean. Lazzari et al. [2011] coupled a nine-plankton functional type biogeochemical model [BFM, Vichi et al., 2007] to an eddy-resolving ocean model [OPAMED16, Béranger et al., 2010]. They correctly reproduced the interannual variability of the key biogeochemical components at the Mediterranean scale over a 6 year period.

[6] The objectives of the present study are to assess and understand the response of NWMS pelagic planktonic eco- systems to the atmospheric and oceanic interannual variability. Surface chlorophyll concentration and primary production satellite data show that at the scale of the whole Mediterranean basin, the Northwestern basin is quite homogeneous [Bosc et al., 2004]. The object of this paper is therefore to study the role of this area as a whole entity in terms of functioning, variability of ecosystems and associated carbon cycle. For that, we adopt a numerical approach based on the coupling between an eddy-resolving ocean circulation model and a multinutrients and multiplankton functional type model. The use of an eddy-resolving ocean model is indeed essential given the major role that mesoscale processes play in deep convection [Herrmann et al., 2008a] and nutrients mixing [Lévy et al., 2001]. The numerical tools and simulations are described in section 2 . We performed statistical and budget analysis over the domain to examine the response of the main biogeochemical variables and processes to the interannual variability of winter atmospheric and oceanic conditions. They are presented and commented in section 3 . Results are discussed and conclusions are presented in section 4 .

\section{Tools}

\subsection{The Physical Model}

[7] The 3-D primitive equation ocean model SYMPHONIE is used to compute the evolution due to the hydrodynamics of the planktonic pelagic ecosystem in the NWMS. This model is described in detail in Marsaleix et al. [2009, $2011,2012]$. It was used to study the circulation in the NWMS, in particular deep water formation over the shelf [Ulses et al., 2008; Herrmann et al., 2008b] and in the open ocean [Herrmann et al., 2008a; Herrmann and Somot, 2008]. The horizontal grid is orthogonal and eddyresolving: the $3 \mathrm{~km}$ grid spacing is 3.5 times smaller than the first Rossby deformation radius in this region. A 40 vertical levels hybrid sigma-step coordinates system is used. The horizontal viscosity is $60 \mathrm{~m}^{2} \mathrm{~s}^{-1}$. Vertical eddy viscosities and diffusivities are calculated according to the Gaspar et al. [1990] second-order closure scheme. In case of unstable stratification, a nonpenetrative convective adjustment algorithm is used [Madec et al., 1991]. At the surface, the model is forced by air-sea fluxes (heat flux, water flux, and wind stress). The large-scale oceanic forcing terms are applied at the open boundaries following the nesting method described in Auclair et al. [2006] and Estournel et al. [2009]. The Rhone river freshwater discharge is introduced as a lateral boundary condition. The area covered by the tridimensional numerical grid is shown in Figure 1.

\subsection{The Biogeochemical Model}

[8] The biogeochemical model is a multinutrient and multiplankton functional types model that simulates the dynamics of several biogeochemical decoupled cycles of biogenic elements (carbon, nitrogen, phosphorus, and silicon) and of nonredfieldian plankton groups. The model structure used in this study is based on the same pelagic plankton ecosystem model as the one fully described and used by Herrmann [2007, chap. 5] and Auger et al. [2011]. There are six main groups (zooplankton, phytoplankton, heterotrophic bacteria, particulate organic matter (POM, small (S) and large (L)), dissolved organic matter (DOM) and 


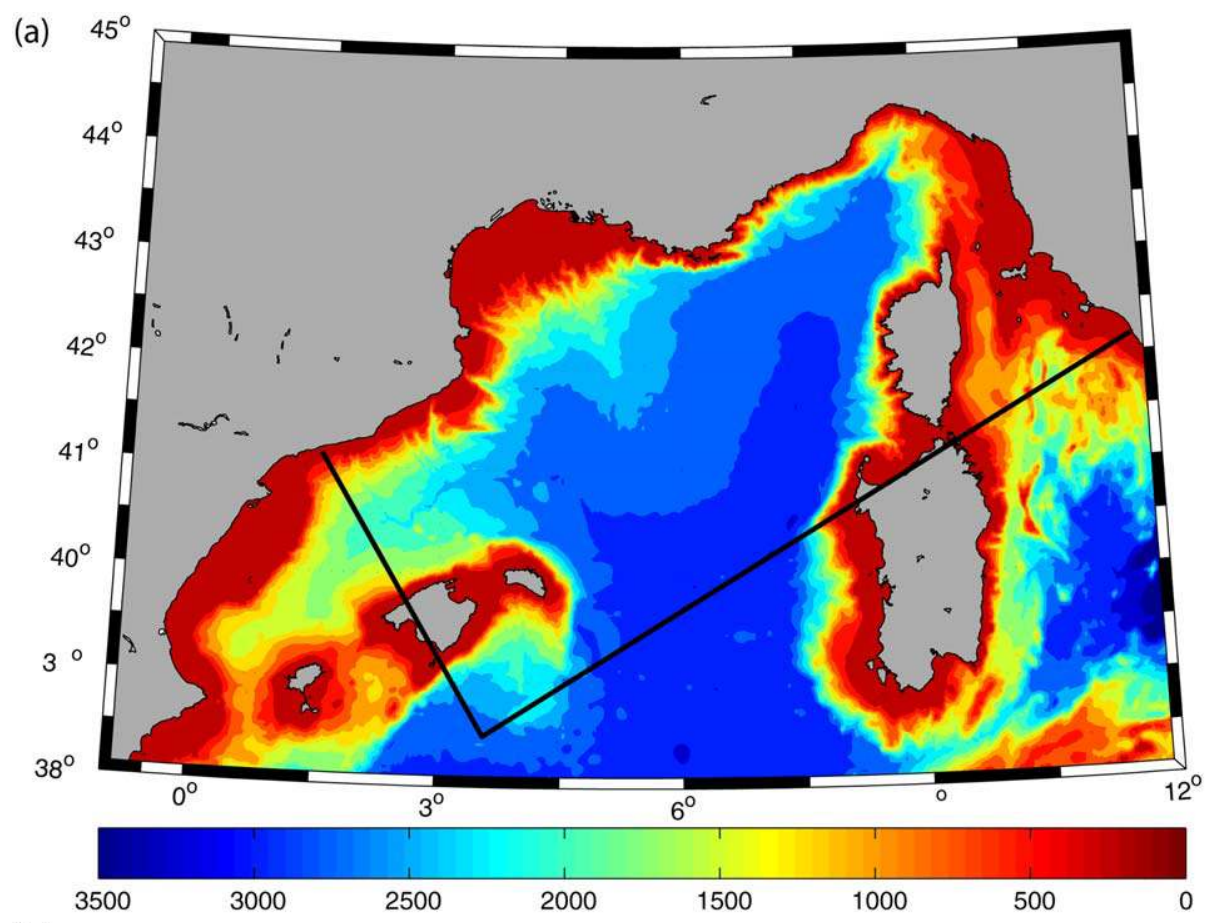

(b)


(c)

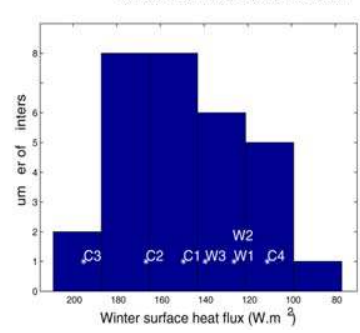

(e)

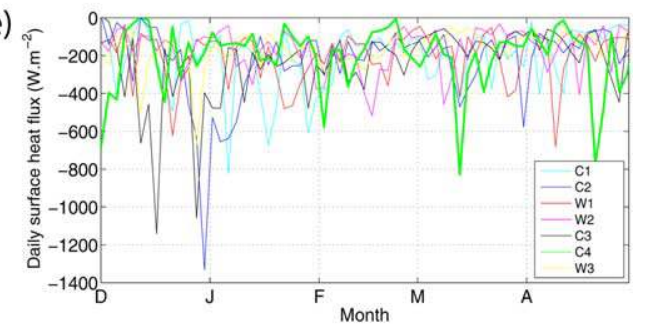

Figure 1. (a) Bathymetry (m) of the NWMS. The thick black line indicates the boundary of the model domain. (b) Evolution for the 30 first years of the simulation of Somot et al. [2006] of $H_{D J F}$, the atmospheric heat flux averaged between December and February over the domain. (c) Distribution of $H F_{D J F}$ over these 30 years. Evolution of the (d) monthly, and (e) daily heat flux between December and April for the seven selected years.

nutrients (or dissolved inorganic matter, DIM)), and 33 state variables. Figure 2 shows a synthetic scheme with the functional groups, their chemical constituents and the biogeochemical processes. The description of phytoplankton is derived on the mechanistic formulations modeling platform Eco3M [Baklouti et al., 2006a, 2006b]. The description of zooplankton and bacteria is based on the model of Anderson and Pondaven [2003] adapted by Raick et al. [2005] for multigroup and multielement modeling in the Ligurian Sea.

[9] Eco3M was used to study the impact of coastal mesoscale eddies on the spatial distributions of nutrients and plankton in the western part of the Gulf of Lions
(R. Campbell et al., Nutrients and plankton spatial distributions induced by a coastal eddy in the Gulf of Lion. Insights from a numerical model, submitted to Progress in Oceanography, 2013). Fontana et al. [2009] performed chlorophyll data assimilation into the coupled SYMPHONIEEco3M model, improving the realism of coupled simulations over a NWMS coastal zone. Auger et al. [2011] used and calibrated this coupled model to study the pelagic ecosystem in the Rhone river plume. As the present study deals with the whole NWMS there are some differences with the Auger et al.'s [2011] version: the set of the biogeochemical parameters was adapted to the representation of pelagic ecosystems dynamics in the offshore areas of the study 


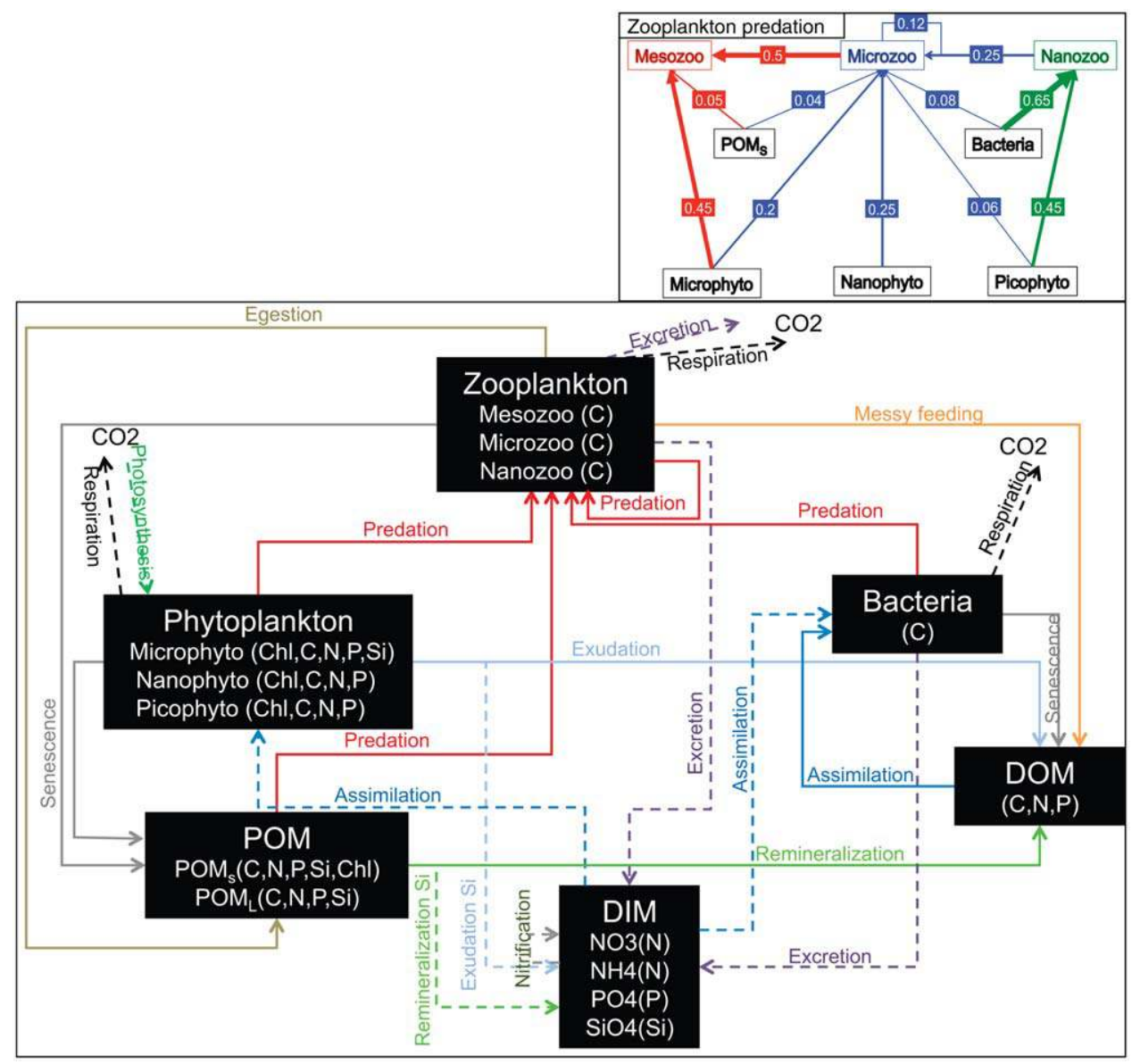

Figure 2. The ecosystem pelagic planktonic model: functional groups, chemical constituents, and biogeochemical processes. Solid, respectively, dotted lines show the fluxes of organic, respectively inorganic matter. Note that DOC contains only the labile and semilabile fractions. The part of refractory DOC (40 mmolC m ${ }^{-3}$ in the western Mediterranean basin) [Santinelli et al., 2012] must be added to the model results to compare them with field values. The right-top plot shows in details the predation links, with numbers and line thicknesses corresponding to the values of the zooplankton preference coefficients [see Herrmann, 2007; Auger et al., 2011].

zone, there is no state variable for particulate inorganic matter from terrestrial origin and the impact of colored DOM is not taken into account. The detailed values of the parameters are provided in Herrmann [2007, Table 5.1].

\subsection{The Coupling Principle}

[10] The spatiotemporal evolution of a biogeochemical tracer of concentration $C$ is given by:

$$
\underbrace{\frac{\partial C}{\partial t}}_{(1)}+\underbrace{\frac{\partial u C}{\partial x}+\frac{\partial v C}{\partial y}+\frac{\partial\left(w-w_{\text {sed }}\right) C}{\partial z}}_{(2)}=\underbrace{\frac{\partial}{\partial z}\left(K_{v} \frac{\partial C}{\partial z}\right)}_{(3)}+\underbrace{\left.\frac{\partial C}{\partial t}\right|_{B G C}}_{(4)}
$$

[11] The term (1) corresponds to the temporal variation. The three following terms (2) correspond to the horizontal and vertical advection, $w_{\text {sed }}$ being the settling velocity. Equation (3) corresponds to the diffusion with $K_{v}$ the vertical diffusion coefficient and (4) to the variation associated with the biogeochemical processes. The biogeochemical model enables to compute this last term, while the physical model is used to compute the other terms. Butenschön et al. [2012] compared two coupling methods: the Operator Splitting and the Source Splitting methods. The Operator Splitting method separates the system into two separate subsystems, governed, respectively, by the physical and the biological processes, that are solved sequentially. The Source Splitting method uses the fact that the physical timescale is much smaller than the biogeochemical timescale, and solves biogeochemical rates at coarser time step than transport processes. Butenschön et al. [2012] showed that for Eulerian coupled hydrodynamical-biogeochemical models, Source Splitting is more relevant than Operator Splitting since it produces lower errors and is computationally cheaper. We use the Source Splitting method, using the physical time steps of Herrmann et al. [2008b] of the order of a few seconds, and taking a biogeochemical time step equal to $1 \mathrm{~h}$. Strictly speaking, as for many models [Lazzari et al., 2010], the biogeochemical model is actually forced by the hydrodynamical model and not coupled with it: the influence of the biogeochemical processes on the 
hydrodynamical ones is considered as negligible [Mann and Lazier, 1991]. We therefore performed "offline" biogeochemical runs forced by the results of the hydrodynamical simulations.

\subsection{The Simulations}

\subsubsection{Hydrodynamics}

[12] The hydrodynamical settings of the simulations were described by Herrmann et al. [2008b] who studied the impact of atmospheric interannual variability on dense water formation over the Gulf of Lions shelf. Results of an oceanic simulation performed for the 1960-2099 period over the whole Mediterranean Sea by Somot et al. [2006] using the OPAMED8 eddy-permitting model were used to prescribe the initial and lateral boundary hydrodynamical conditions. Lateral boundary conditions for SYMPHONIE (temperature, salinity, horizontal velocity, and sea surface elevation) were provided at each time step by the timeinterpolated monthly averaged results of the simulation performed with OPAMED8. Boundary conditions have a double objective: the radiation of outgoing waves and the forcing of the inner solution by external fields provided by the basin model. This is achieved by applying our open boundary conditions schemes on the difference between the modeled and external variables rather than on the absolute variables following Marsaleix et al. [2006]. OPAMED8 outputs were made consistent with SYMPHONIE characteristics using the variational inverse method VIFOP described by Auclair et al. [2006]. At the surface, SYMPHONIE was forced by air-sea fluxes (heat flux, water, and momentum air-sea fluxes) at a daily frequency. To force OPAMED8 and our model at the surface, air-sea fluxes were provided by a run performed with the atmospheric regional climate model ARPEGE-Climate for the 1960-2099 period [Somot et al., 2006]. This atmospheric simulation is divided into two periods. During the first 40 years, the greenhouse gases and aerosols concentrations correspond to the concentrations observed between 1960 and 1999. During the following 100 years, these concentrations increase following the IPCC A2 scenario [IPCC, 2001]. Note that the initial conditions of this simulation correspond to the real January 1960 conditions, but that there is no data assimilation in the atmospheric simulation: it is realistic from a climatological point of view, but, due to the atmospheric chaotic behavior, a climate model year does not correspond to the actual year with the same number. For example, year number 1962 is just the third year of the simulation, and one should not expect this year to follow the chronology of the real year 1962. We use the same Rhône discharge as Somot et al. [2006], based on the climatological monthly UNESCO RivDis database [Vörösmarty et al., 1996].

[13] Since it was not technically possible to perform a multidecadal coupled simulation at a $3 \mathrm{~km}$ resolution, we selected seven representative years of the present climate period [defined as the 1961-1990 period of the ARPEGEClimate simulation following the PRUDENCE project, Christensen et al., 2002]. As explained above deep convection plays a major role in the NWMS circulation and strongly influences the dynamics of the pelagic planktonic ecosystem. Since the strength of deep convection is related to winter surface heat flux [Herrmann et al., 2010], we examined surface heat flux averaged over the coldest period, i.e., December-February, $H F_{D J F}$, and over the model domain for the present period of the ARPEGE-Climate simulation (Figure 1b). We selected seven representative years (blue $\mathrm{C} 1, \mathrm{C} 2, \mathrm{C} 3, \mathrm{C} 4, \mathrm{~W} 1, \mathrm{~W} 2, \mathrm{~W} 3$ ) with winter heat flux distributed over the whole range of the heat flux values (Figure 1c). We then performed seven corresponding simulations of the NWMS circulation using SYMPHONIE. Those hydrodynamic simulations are analyzed in details in Herrmann et al. [2008b]. Results of those hydrodynamical simulations are used to force the biogeochemical model in order to compute the tridimensional evolution of the pelagic planktonic ecosystem over the NWMS during those 7 years.

\subsubsection{Biogeochemical Initial Conditions}

[14] When performing our simulations, no experimental data or numerical results were available over the studied area to perform a tridimensional varying initialization of the biogeochemical variables. We therefore adopted the following method: we used vertical profiles obtained at DYFAMED on 20 January 2004, i.e., at a period when the water column was vertically mixed hence the most homogeneous, to initialize the biogeochemical variables over the whole domain. We then performed a biogeochemical simulation beginning in January and forced 5 years in loop by the results of the average year $\mathrm{C} 4$ hydrodynamical simulation. In September of the third year of this simulation, the annual cycle of the biogeochemical variables was stabilized: after this time, the temporal evolution of each biogeochemical variable repeated itself quasi identically for all the following annual loops. Raick et al. [2005] obtained the same stabilization time length in the Ligurian Sea. We then used the biogeochemical tridimensional fields of this loop simulation in September of the third year to provide initial conditions to seven different annual biogeochemical simulations. These seven simulations were forced by the daily atmospheric fields of the 7 years selected above and by the oceanic fields of the corresponding seven hydrodynamical simulations. They ran from September to next September. At the end, we obtained seven annual biogeochemical simulations that can be considered as the twins of the hydrodynamical simulations analyzed in Herrmann et al. [2008b].

[15] Initial vertical profiles of the main biogeochemical variables obtained by the model spin-up at the center of the convection area $\left(42^{\circ} \mathrm{N}, 5^{\circ} \mathrm{E}\right)$ are shown on Figure 3. Data collected during the BOUM Experiment in summer 2008 [Moutin et al., 2012] enable to check the realism of those profiles. The values observed at $\left[42^{\circ} \mathrm{N}, 5^{\circ} \mathrm{E}\right]$ during BOUM are presented in Table 1. Most of our vertical profiles show the same shape as observations, with similar depths of maximum. Nitrate and phosphate concentrations at depth larger than $1000 \mathrm{~m}$ are underestimated in our initial profiles, but remain in the range of concentrations observed in the Mediterranean basin [Pujo-Pay et al., 2011, Table 2]. The vertical silicate gradient is underestimated with too large concentrations at the surface and too low ones at $200 \mathrm{~m}$ [Crombet et al., 2011]. Ammonium concentrations in the upper layer are significantly overestimated in our initial profiles [Pujo-Pay et al., 2011]. Taking into account the refractory part of DOC $\left[40 \mathrm{mmolC} \mathrm{m} \mathrm{m}^{-3}\right.$, Santinelli et al., 2012], the modeled DOC concentrations correctly match those observed. The initial total chlorophyll profile reproduces the typical summer shape with a deep maximum of 

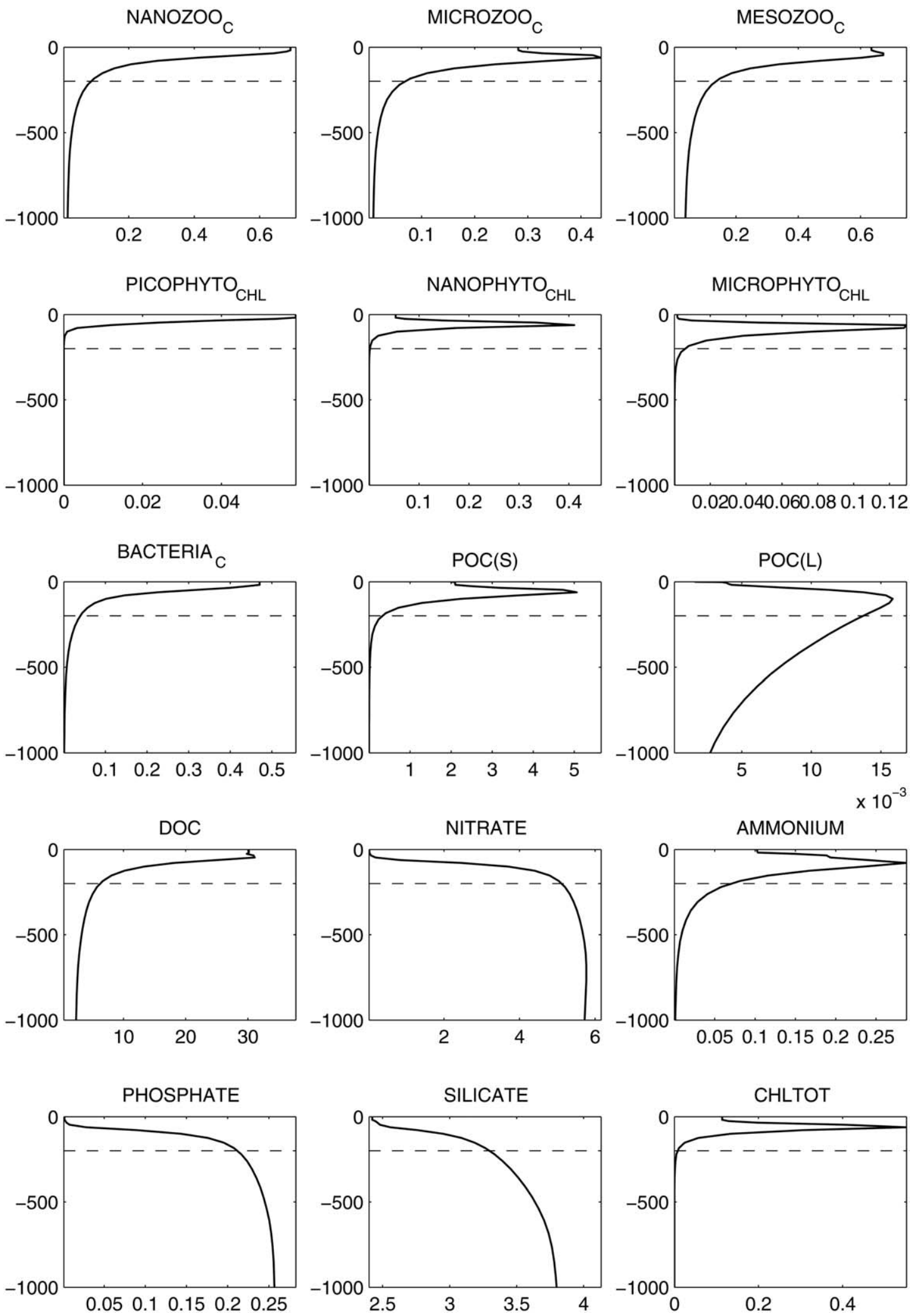

Figure 3. Initial profiles of the main biogeochemical variables at the center of the convection area $\left[42^{\circ} \mathrm{N}, 5^{\circ} \mathrm{E}\right]$. The indexes correspond to the constituent element whose concentration is shown. Units are $\mathrm{mmol}(\mathrm{C}, \mathrm{N}, \mathrm{P}, \mathrm{Si}) \mathrm{m}^{-3}$ except for chlorophyll $\left(\mathrm{mgChl} \mathrm{m}^{-3}\right)$. The dotted line shows the $200 \mathrm{~m}$ depth. 
Table 1. Ranges and Depths of Maximum Values of Some Biogeochemical Variables Measured at $\left[42^{\circ} \mathrm{N}, 5^{\circ} \mathrm{E}\right]$ During the BOUM Cruise [Moutin et al., 2012]

\begin{tabular}{|c|c|c|c|}
\hline Variable &  & Depth of max (m) & Reference \\
\hline Nitrate & {$[<0.05-9.6]$} & $400-1900$ & Pujo-Pay et al. [2011] \\
\hline Phosphate & {$[<0.01-0.42]$} & $500-1200$ & Pujo-Pay et al. [2011] \\
\hline Ammonium & {$[<0.001-0.005]$} & Surface & Pujo-Pay et al. [2011] \\
\hline Silicate $^{\mathrm{b}}$ & {$[<1.0-5.2]$} & 200 & Crombet et al. [2011] \\
\hline Chlorophyll $^{\mathrm{b}}$ & {$[<0.2-0.6]$} & 50 & Crombet et al. [2011] \\
\hline DOC & {$[39-70]$} & Surface & Pujo-Pay et al. [2011] \\
\hline $\mathrm{POC}^{\mathrm{c}}$ & {$[<1.5-8.7]$} & Surface & Pujo-Pay et al. [2011] \\
\hline Heterotrophic Bacteria ${ }^{\mathrm{d}}$ & {$[0.15-0.7]$} & 70 & Christaki et al. [2011] \\
\hline Heterotrophic nanoflagellates ${ }^{\mathrm{d}}$ & {$[0.01-0.8]$} & 10 & Christaki et al. [2011] \\
\hline Microzooplankton $^{\mathrm{d}}$ & {$[0.009-0.14]$} & 70 & Christaki et al. [2011] \\
\hline Mesozooplankton $^{\mathrm{b}}$ & {$[0.04-0.16]$} & 50 & Nowaczyk et al. [2011] \\
\hline
\end{tabular}

${ }^{a}$ Heterotrophic bacteria abundance is converted into biomass using the usual carbon conversion factor of 12 fgC cell $^{-1}\left[\mathrm{Fukuda}_{\mathrm{et}}\right.$ al., 1998$]$. Heterotrophic nanoflagellates abundance is converted into biomass using the mean biovolume of $20 \mu \mathrm{m}^{3}$ cell $^{-1}$ [Tanaka and Rassoulzadegan, 2002] and the carbon conversion factor of $183 \mathrm{fgC} \mu \mathrm{m}^{-3}$ [Caron et al., 1995]. Microzooplankton (total ciliates) abundance is converted into biomass using the mean biovolume of $11,000 \mu \mathrm{m}^{3}$ cell ${ }^{-1}$ [Tanaka and Rassoulzadegan, 2002] and the carbon conversion factor of $0.19 \mathrm{pgC}^{2} \mathrm{~m}^{-3}$ [Putt and Stoecker, 1989]. Mesozooplankton (small copoepods $<1 \mathrm{~mm}$ ) abundance is converted into biomass using the carbon conversion factor of $0.04 \mathrm{mgC}^{-1}\left[\right.$ Razouls and $^{-1}$ Razouls, 1976].

${ }^{\mathrm{b}}$ Ranges of values available over 0-200 $\mathrm{m}$ depth.

${ }^{\mathrm{c}}$ Ranges of values available over $0-300 \mathrm{~m}$ depth.

${ }^{\mathrm{d}}$ Ranges of values available over $0-150 \mathrm{~m}$ depth.

$0.5 \mathrm{mg} \mathrm{m}^{-3}$ around $50 \mathrm{~m}$ [Crombet et al., 2011]. The maxima of nanoflagellates and bacteria biomasses and their respective locations in the vertical water column correspond to observations [Christaki et al., 2011]. The model catches the vertical shapes of microzooplankton and mesozooplankton but the modeled maxima are overestimated [Christaki et al., 2011; Nowaczyk et al., 2011]. It must be kept in mind that the BOUM is a punctual data set that cannot reflect the spatial and temporal variability of biogeochemical variables. One can reasonably conclude from those comparisons that the initialization state used in this work is realistic.

\subsubsection{Biogeochemical Boundary Conditions}

[16] For the same reasons as for the initial conditions, no information concerning the fluxes at the lateral boundaries was available. To overcome this problem we applied a buffer zone of 20 points along the lateral open boundaries: the horizontal advection is switched off in this buffer zone to avoid applying to the biogeochemical variables strong vertical advections and velocities potentially induced by the boundary conditions from the hydrodynamics. The solution is then smoothed over the buffer zone in order to eliminate strong unrealistic horizontal gradients that can appear along the boundary: for incoming fluxes the value of $C$ at the first point of the domain where the model runs tridimensionally is given by the average of the 20 points of the buffer zone. For the outgoing fluxes, the concentration is computed "classically" using the values of the inner domain.

[17] Data available to assess the fluxes of organic and inorganic matter of atmospheric origin are extremely scarce. Moreover those fluxes are highly episodical and can therefore be considered as globally negligible. We did not take them into account in this study. Nutrients and organic matter fluxes at the sea bottom due to diagenesis or sediment resuspension were also neglected.

[18] For nutrients and dissolved and particulate organic matter coming from the Rhone river, we applied the monthly in situ concentration data provided by the
"Rhone-Mediterranee" monitoring network (http:// www.rdbrmc.com/cartordbrmc/) for 2003-2004. The annual mean of those values is shown in Table 2 .

\section{Impact of Atmospheric and Oceanic Interannual Variability on the NWMS Pelagic Planktonic Ecosystem}

[19] In this section, we analyze the results of the seven annual coupled simulations: our goals are to evaluate how the model reproduces the seasonal evolution of the NWMS

Table 2. Yearly Average Value of the Concentrations of Small and Large Particulate Organic Matter and Dissolved Organic and Inorganic Matter at the Rhone Mouth ${ }^{\mathrm{a}}$

\begin{tabular}{|c|c|}
\hline Variable & Concentration value \\
\hline \multicolumn{2}{|c|}{ Small Particulate Organic... } \\
\hline Carbon $\mathrm{POC}_{S}$ & 36.00 \\
\hline Nitrogen $\mathrm{PON}_{S}$ & 6.00 \\
\hline Phosphorus $\mathrm{POP}_{S}$ & 0.38 \\
\hline 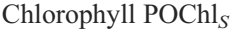 & 0.00 \\
\hline Silicon $\mathrm{POSi}_{S}$ & 0.00 \\
\hline \multicolumn{2}{|c|}{ Large Particulate Organic... } \\
\hline Carbon $\mathrm{POC}_{L}$ & 6.60 \\
\hline Nitrogen $\mathrm{PON}_{L}$ & 1.10 \\
\hline Phosphorus $\mathrm{POP}_{L}$ & 0.07 \\
\hline Silicon $\mathrm{POSi}_{L}$ & 1.10 \\
\hline \multicolumn{2}{|l|}{ Dissolved Organic.... } \\
\hline Carbon DOC & 12.00 \\
\hline Nitrogen DON & 2.00 \\
\hline Phosphorus DOP & 0.12 \\
\hline \multicolumn{2}{|l|}{ Nutrients } \\
\hline Nitrate $\mathrm{NO}_{3}$ & 96.91 \\
\hline Ammonium $\mathrm{NH}_{4}$ & 3.99 \\
\hline Phosphate $\mathrm{PO}_{4}$ & 1.53 \\
\hline Silicate $\mathrm{SiO}_{4}$ & 53.84 \\
\hline
\end{tabular}

${ }^{\mathrm{a}}$ Units are $\mathrm{mmol}(\mathrm{C}, \mathrm{N}, \mathrm{P}, \mathrm{Si}) \mathrm{m}^{-3}$ except for chlorophyll $\left(\mathrm{mgChl} \mathrm{m}^{-3}\right)$. 
pelagic planktonic ecosystem, and to study the response of this ecosystem to atmospheric and oceanic interannual variability under present climate conditions at the scale of the whole region.

\subsection{Hydrodynamic Characteristics}

[20] Oceanic convection plays a major role in the NWMS oceanic circulation and biological activity. Studies by Somot et al. [2006], Herrmann and Somot [2008], and Herrmann et al. [2008a, 2008b, 2010] were specifically dedicated to the modeling of NWMS convection. They showed that the hydrodynamical model SYMPHONIE reproduces realistically convection functioning and variability at different space and time scales and that convection interannual variability is strongly related to the winter atmospheric buoyancy loss variability. We refer the reader to those papers for the detailed analysis of the hydrodynamical simulations, and only present here the points that will be relevant for the analysis of the biogeochemical simulations.

[21] The mixed layer depth (MLD) at each model grid point is defined using a threshold value of $4 \mathrm{~cm}^{2} \mathrm{~s}^{-1}$ for the vertical diffusion coefficient [Herrmann et al., 2008a]. Figure 4 shows the annual cycle of the MLD averaged over the NWMS, MLD ${ }_{N W M S}$, and of the temperature averaged over the NWMS and the upper $200 \mathrm{~m}, T_{N W M S}$. The $200 \mathrm{~m}$ layer was chosen to compute average values for the different ecosystem components because it corresponds to the base of the nutricline and more generally because it contains most of the planktonic components and includes the euphotic layer, as can be seen on vertical profiles in Figure 3.

[22] The region of convection, corresponding to the region of high surface water density $\left(>29.1 \mathrm{~kg} \mathrm{~m}^{-3}\right)$, is localized around $\left[42^{\circ} \mathrm{N}, 5^{\circ} \mathrm{E}\right]$ (Figure 5), in agreement with MEDOC-Group [1970]. The strong interannual variability of deep convection intensity is reproduced in our simulations, with years where MLD $_{N W M S}$ does not exceed $200 \mathrm{~m}$ and years where it exceeds $1000 \mathrm{~m}$. The standard deviation of the annual mean of $\mathrm{MLD}_{N W M S}$ among the seven annual simulations is equal to $52 \%$ (Table 3 ). The duration of deep convection is also highly variable with years where it stops at the beginning of March and other where it occurs until April. Stronger deep convection is associated with colder surface layer: we obtain a correlation coefficient of -0.85 (SL >0.9999) between the annual mean of $T_{N W M S}$ and the annual mean of $\mathrm{MLD}_{N W M S}$. This cooling results both from the strong atmospheric heat loss that induces deep convection and from the vertical mixing of the water column that injects cold deep water up to the surface.

[23] $H F_{D J F}$ is larger than the average for "warm" years W1, W2, W3, i.e., the sea looses less heat than the average (Figure 1b). During these years, winter convection is weak with annual $\mathrm{MLD}_{N W M S}$ between 52 and $70 \mathrm{~m}$, smaller than the $130 \mathrm{~m}$ average value (Table 3 and Figure 4). The $200 \mathrm{~m}$ upper layer is warm with annual $T_{N W M S}$ between 16.1 and $16.2^{\circ} \mathrm{C}$ larger than the $15.9^{\circ} \mathrm{C}$ average (Table 3 and Figure 4). $H F_{D J F}$ is lower than or equal to the average for "cold" years C1, C2, and C3. During these years, winter convection is strong with annual $\mathrm{MLD}_{N W M S}$ around $190 \mathrm{~m}$. The $200 \mathrm{~m}$ upper layer is cold, with annual $T_{N W M S}$ of,
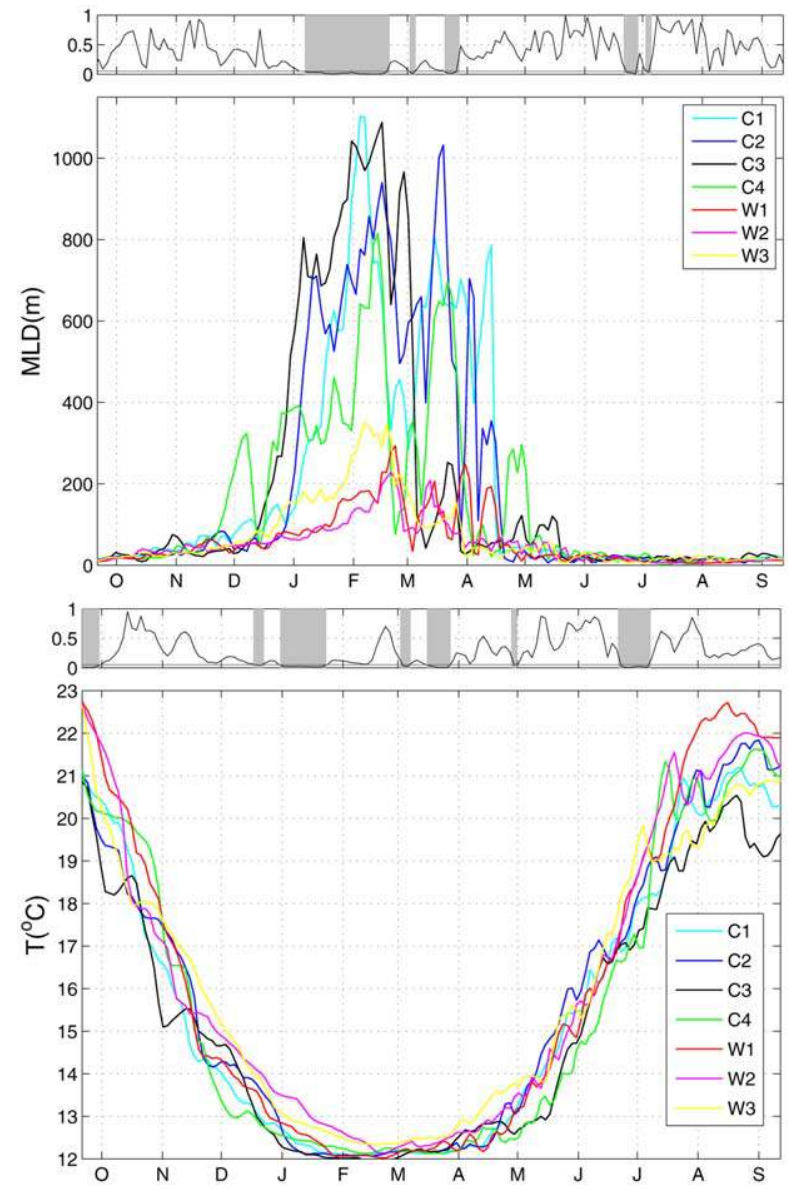

Figure 4. Time series for the seven annual simulations of the mixed layer depth and of the mean 0-200 m temperature averaged over the whole domain, $\operatorname{MLD}_{N W M S}$ and $T_{N W M S}$. The black line above each graph shows the evolution of the associated $p$ value, with periods of $p<0.05$ highlighted in gray (see section 3.1).

respectively, $15.7,15.9$, and $15.3^{\circ} \mathrm{C}$. Year $\mathrm{C} 4$ shows a particular behavior. It is the year with the weakest $H F_{D J F}$ among the 7 years group (Figure $1 \mathrm{~b}$ ). However it leads to an ocean behavior closer to the " $\mathrm{C}$ " years than to the " $\mathrm{W}$ " years, with an annual $\operatorname{MLD}_{N W M S}(153 \mathrm{~m})$ larger and an annual $T_{N W M S}\left(15.7^{\circ} \mathrm{C}\right)$ colder than the average. The explanation for this is provided by Figures $1 \mathrm{~d}$ and $1 \mathrm{e}$ where we show the detailed monthly and daily evolutions of the air to sea heat flux over the modeled domain for each selected year. Heat loss over the modeled domain in January is particularly weak for C4. December and February heat losses are average. This results in mean December-February heat loss that is the weakest among the 7 years. But March and April heat losses of $\mathrm{C} 4$ are the strongest. Moreover, this winter, six strong atmospheric events with average heat loss larger than $400 \mathrm{~W} \mathrm{~m}^{-2}$ occur, at beginning of December, mid-December, beginning of February, mid-May, and mid-April. As a result, for year $\mathrm{C} 4$, convection occurs, resulting in an annual $\operatorname{MLD}_{N W M S}(153 \mathrm{~m})$ larger than the $130 \mathrm{~m}$ average though smaller than the values around 190 $\mathrm{m}$ obtained for years $\mathrm{C} 1, \mathrm{C} 2$, and C3. Mixed layer deepening follows the strong events mentioned above (Figure 4). 

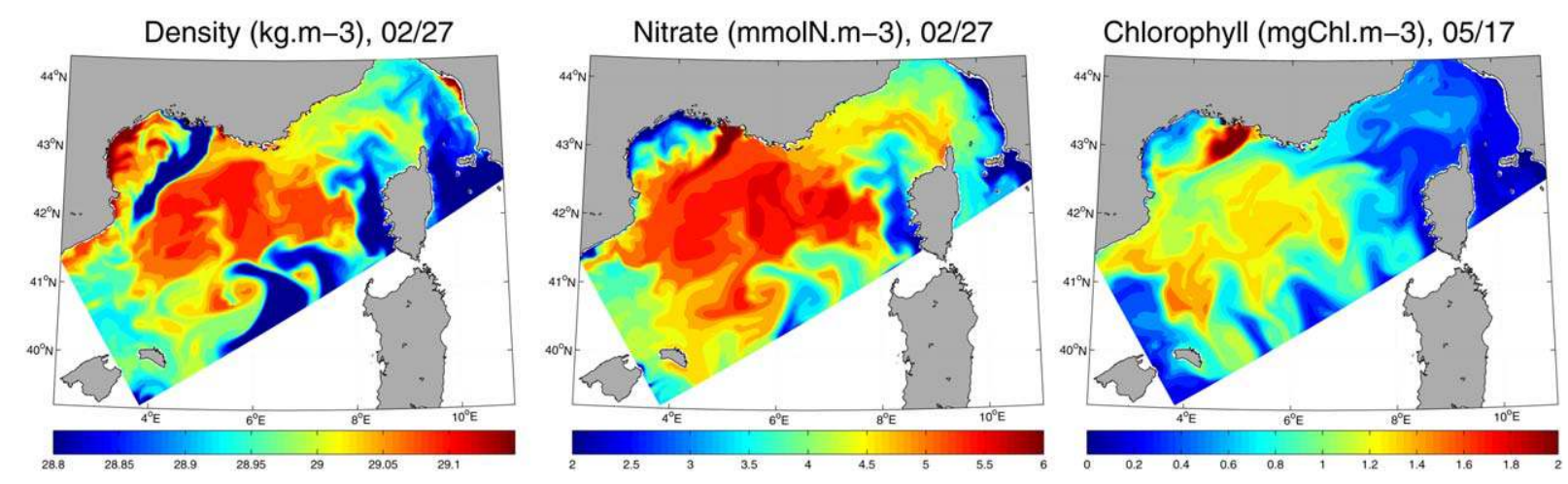

Figure 5. (left) Surface density and (middle) nitrate concentration on end of February and (right) surface chlorophyll concentration on mid-May for year $\mathrm{C} 1$.

Consequently to this and to the strong heat loss between February and April, the upper layer temperature at the beginning of May is the lowest (Figure 4). Finally, from the point of view of the physical oceanic behavior, $\mathrm{C} 4$ is closer to the "C" years than from "W" years. This analysis of the differences of physical characteristics between the selected years therefore shows that these years can be divided into two groups: a group with years of very strong $(\mathrm{C} 1, \mathrm{C} 2$, and C3) and strong (C4) convection and cold upper $200 \mathrm{~m}$ layer (group C), and a group with years of weak convection and warm upper layer (W1, W2, W3, group W).

[24] We obtain a correlation coefficient of $-86 \%$ (SL $>0.984$ ) between the annual $\mathrm{MLD}_{N W M S}$ and the mean December-March winter surface heat flux over the domain,

Table 3. Interannual Variability of the NWMS Atmospheric, Hydrodynamics and Main Biogeochemical Variables and Processes: Average Annual Value Obtained for Each of the Seven Simulations, Average Over Those Simulations, Absolute and Relative Standard Deviation to this Average, $p$ Value Obtained for the Student $t$ Test Performed Between Averaged Values of Samples (C1, C2, C3, C4) and $(\mathrm{W} 1, \mathrm{~W} 2, \mathrm{~W} 3)^{\mathrm{a}}$

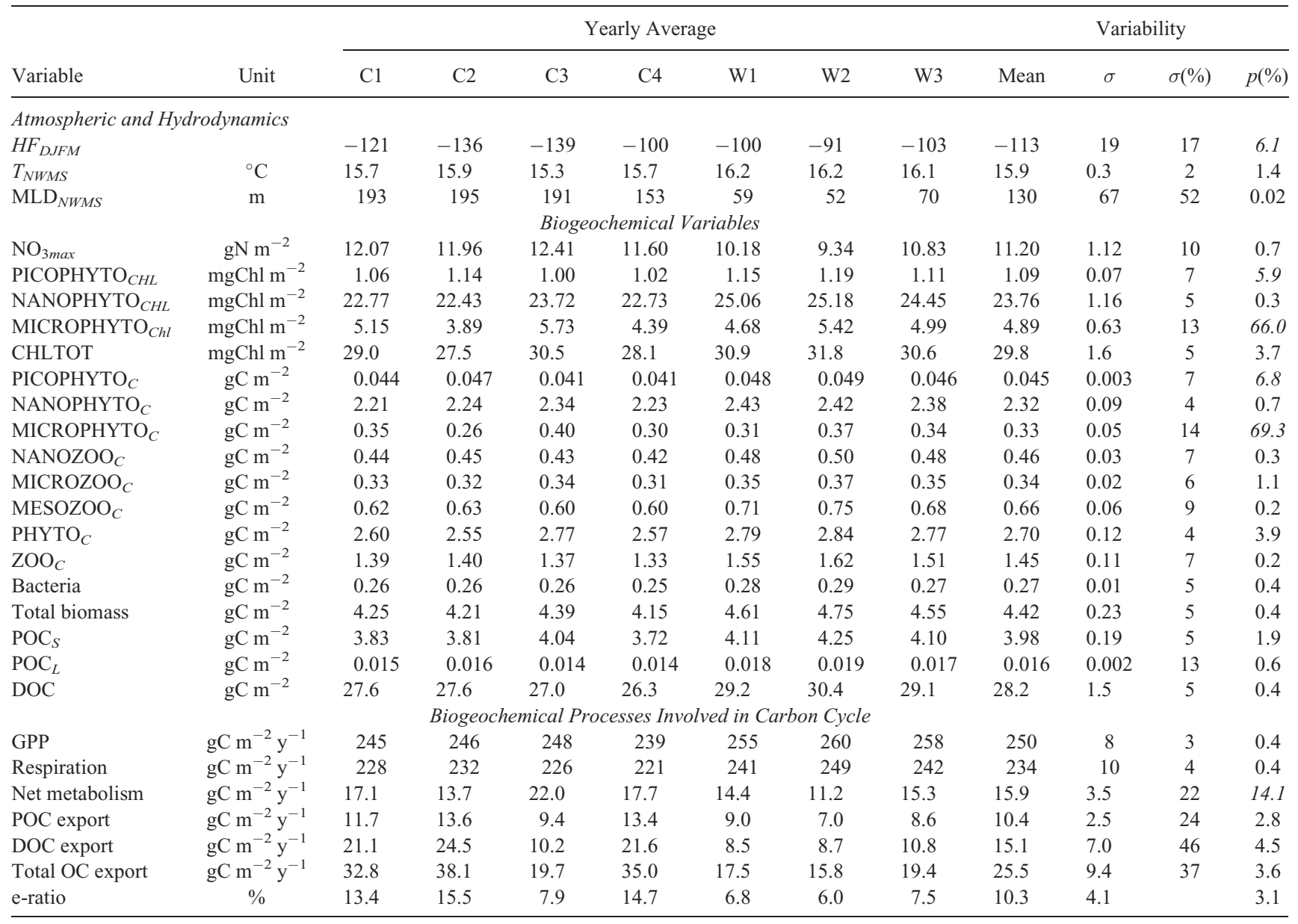

${ }^{\mathrm{a} C}$ Concentrations are integrated over the first $200 \mathrm{~m}$ and averaged over the whole domain. 
$H F_{D J F M}$ (Table 3). Herrmann et al. [2010] studied in details the factors responsible for the interannual variability of deep convection in the NMWS. Using their values, one obtains a correlation coefficient of $-83 \%$ (SL >0.95) between the December-March heat flux and the annual volume of dense water formed, which is also representative of the deep convection intensity and equivalent to our annual $\mathrm{MLD}_{N W M S}$. The interannual variability of winter surface heat loss is therefore largely responsible for the interannual variability of intensity of oceanic deep convection in the NWMS. To determine quantitatively if groups $\mathrm{C}$ and $\mathrm{W}$ are significantly different from each other, we performed statistical hypothesis Student $t$ test between both groups $(\mathrm{C} 1$, $\mathrm{C} 2, \mathrm{C} 3, \mathrm{C} 4$ and $\mathrm{W} 1, \mathrm{~W} 2, \mathrm{~W} 3)$. The goal of the $t$ test is to reject the null hypothesis, here that both groups come from a population with equal mean. For each $t$ test performed, the $p$ value indicates the probability of obtaining the same result of the test if the null hypothesis was right. Classically, one rejects the null hypothesis at a 5\% significance level. In other words, a $p$ value smaller than 0.05 indicates that groups $\mathrm{C}$ and $\mathrm{W}$ are significantly different. $t$ Test are performed for each value of $\mathrm{MLD}_{N W M S}$ and $T_{N W M S}$, and the corresponding evolution of the $p$ value is plotted above their graphs (Figure 4). $t$ Test are also performed for the mean annual values (Table 3). The smallest $p$ values for $\mathrm{MLD}_{N W M S}$ and $T_{N W M S}$ are obtained during the period of strong winter mixing (January-March) when the differences between the $\mathrm{C}$ and $\mathrm{W}$ groups are the strongest (Figure 4). However in general, differences are not always significantly different. This is due to the strong high-frequency variability of $\mathrm{MLD}_{N W M S}$ and $T_{N W M S}$, itself induced by the high frequency variability of the atmospheric forcing: the time scale of a strong and cold north wind event is of a few days, with a quick feedback of the marine layer in terms of mixed layer deepening and cooling. Moreover, these wind events do of course not happen every year at the same moment. As a result, it is not always obvious to see differences between groups $\mathrm{C}$ and $\mathrm{W}$ at a daily timescale. At an annual scale, $p$ values obtained for the annual $\mathrm{MLD}_{N W M S}$ $(1.4 \%)$ and $T_{N W M S}(0.02 \%)$ are however largely below $5 \%$. From the hydrodynamic point of view, the variability of winter atmospheric heat flux therefore induce significant differences of MLD and temperature between groups $\mathrm{C}$ and $\mathrm{W}$ at the annual scale.

\subsection{Interannual Variability of the Pelagic Planktonic Ecosystem Composition}

[25] As explained in section 1, the present study aims to examine the impact of the atmospheric and hydrodynamic interannual variability on the NWMS ecosystem functioning in considering the area of study as a whole. For that, we performed budget analysis, computing the spatial averages over the model domain of the biogeochemical variables and main processes. To aggregate the variables or processes in space and time, we first averaged them spatially over the whole domain at each time step for each year. For a given variable or process, we thus obtained and plot seven time-vectors (Figures 4, 6-9) that allow to examine the temporal evolution of the NWMS ecosystem and the interannual variability of this evolution. $t$ Test were performed for these spatially averaged values and the corresponding $p$ value evolution are plotted above the corresponding graphs, in the same way we did for $\mathrm{MLD}_{N W M S}$ and $T_{N W M S}$. We then computed the time average of these seven time-vectors, obtaining for each year an annual value (seven first columns of Table 3). Finally, we computed the average, the standard deviation (absolute and relative) and the $p$ values associated with these seven annual values (last four columns of Table 3).

\subsubsection{Nutrients Availability}

[26] Nitrate, phosphate, and silicate show globally the same annual cycle (Figure 6). This evolution is similar for the seven simulations. The concentration of those nutrients in the surface layer is minimum in September, when the water column is strongly stratified [the average $\mathrm{MLD}_{N W M S}$ varies between 10 and $20 \mathrm{~m}$ in summer (Figure 4), in agreement with climatological data given by D'Ortenzio et al. [2005]. Nutrients concentration then progressively increases when the stratification weakens: winter vertical mixing brings those nutrients initially present in the deep layers up to the surface. It reaches a maximum in FebruaryMarch during the period of violent mixing, and the surface enriched area corresponds to the region where deep convection occurs (Figure 5). Nutrients concentrations start to decrease in winter when mixed layer is maximum (Figures 4 and 6). This suggests that the initiation of phytoplankton bloom begins in winter. The decrease is the strongest during the spring bloom in May-June then it is slower until September. In average over the domain, maximum winter values are equal to $3.5-5.0 \mathrm{mmolN} \mathrm{m}^{-3}$ for the nitrate, $0.14-0.2 \mathrm{mmolP} \mathrm{m}^{-3}$ for the phosphate and 2.7-3.2 mmolSi $\mathrm{m}^{-3}$ for the silicate. Those values are in agreement with winter values observed at DYFAMED by Marty et al. [2002]: $2-3 \mathrm{mmolN} \mathrm{m}^{-3}, 0.15-0.2 \mathrm{mmolP}$ $\mathrm{m}^{-3}$, and $3 \mathrm{mmolSi} \mathrm{m}^{-3}$. The trophic regime in the NWMS therefore varies seasonally from mesotrophy in winterspring to oligotrophy in summer, following the stratification.

[27] The nitrate concentration in the upper $200 \mathrm{~m}$ layer constitutes our indicator of the nutrients availability in the euphotic layer. The interannual variability of nutrients availability is very small during the stratified period (JuneNovember), when this availability is very weak (Figure 6). It is maximum between December and May, i.e., during the convection and spring bloom periods when the surface enrichment is maximum. During this period, the $p$ value is generally lower than $5 \%$ : the differences between the $\mathrm{C}$ and $\mathrm{W}$ groups are significant. The standard deviation of $\mathrm{NO}_{3 \max }$, the annual maximum of the nutrient availability indicator, is equal to $10 \%$ (Table 3 ), and again the difference between $\mathrm{C}$ and $\mathrm{W}$ groups is significant ( $p$ value equal to $0.7 \%$ ). The surface enrichment being largely due to winter vertical mixing, this interannual variability is strongly correlated with the variability of winter convection intensity: the correlation coefficient between $\mathrm{NO}_{3 \max }$ and the winter maximum of the annual $\mathrm{MLD}_{N W M S}$ is equal to 0.94 (SL >0.998). The variability of atmospheric and oceanic winter conditions hence induces a significant variability of nutrients availability that lasts during the following seasons (spring and part of summer) and at the annual scale.

[28] Ammonium shows a spatial and temporal evolution which is almost opposite to that of the three other nutrients (Figure 6). This is due to the fact that it is not present in deep layers but that it comes from rivers and heterotrophic 

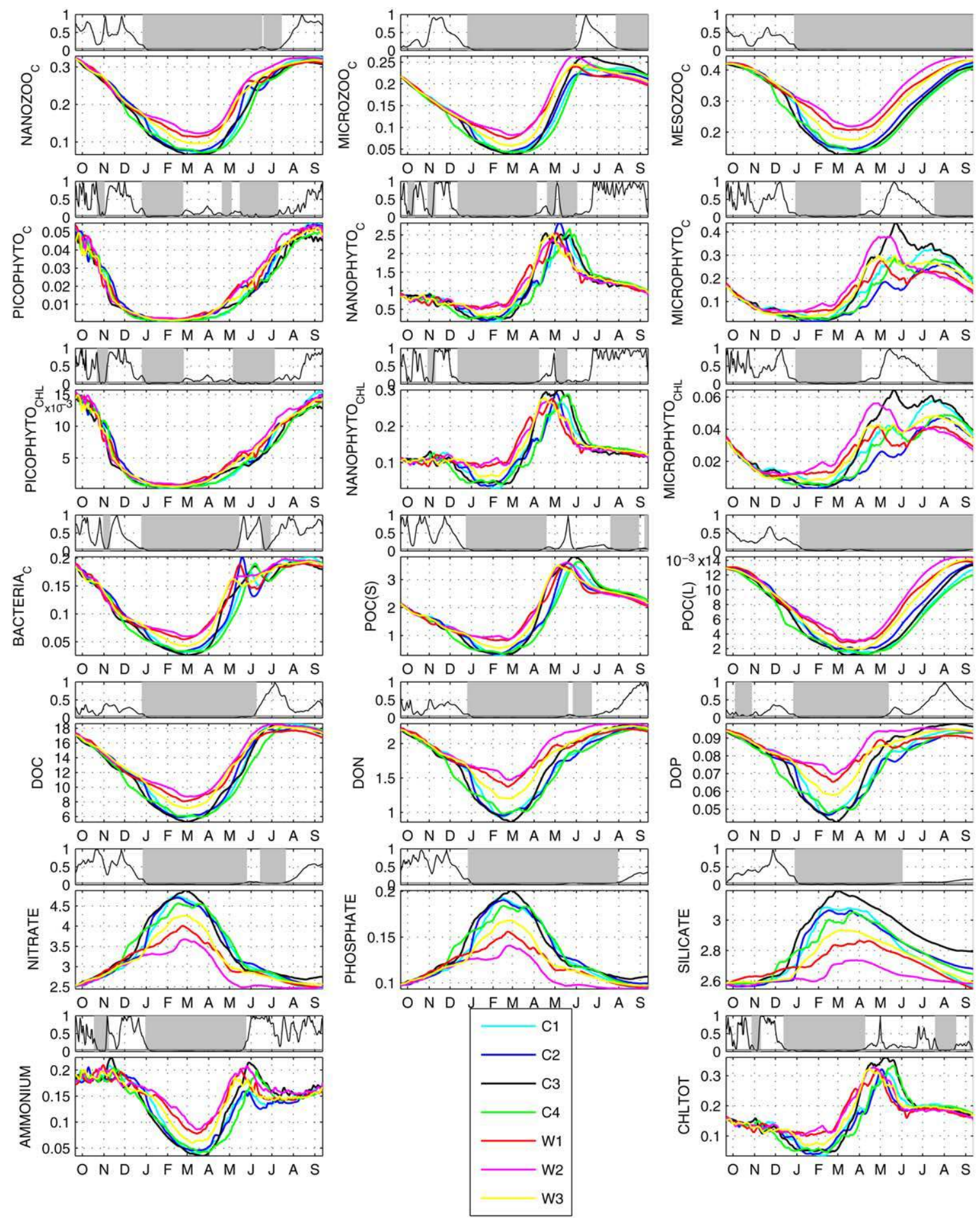

Figure 6. Time series of the biogeochemical variables and associated $p$ value (see section 3.1) for the seven annual simulations: zooplankton, phytoplankton, bacteria, organic matter, nutrients, total chlorophyll. The indexes correspond to the constituent element whose concentration is shown, averaged over the whole domain and over the first $200 \mathrm{~m}$. Units are $\mathrm{mmol}(\mathrm{C}, \mathrm{N}, \mathrm{P}, \mathrm{Si}) \mathrm{m}^{-3}$ except for chlorophyll $\left(\mathrm{mgChl} \mathrm{m}{ }^{-3}\right)$. Periods of $p<0.05$ highlighted in gray.

plankton excretion. This evolution is similar for the seven annual simulations and the concentration range is in agreement with that found in experimental data set [SeguraNoguera et al., 2011]. Ammonium concentration in the surface layer is maximum until November, when it begins to decrease due to its vertical dilution by winter mixing. It reaches a minimum in March-April, and then increases strongly until May-June. This is due to the end of winter convection and the beginning of ammonium excretion associated with the development of heterotrophic plankton 

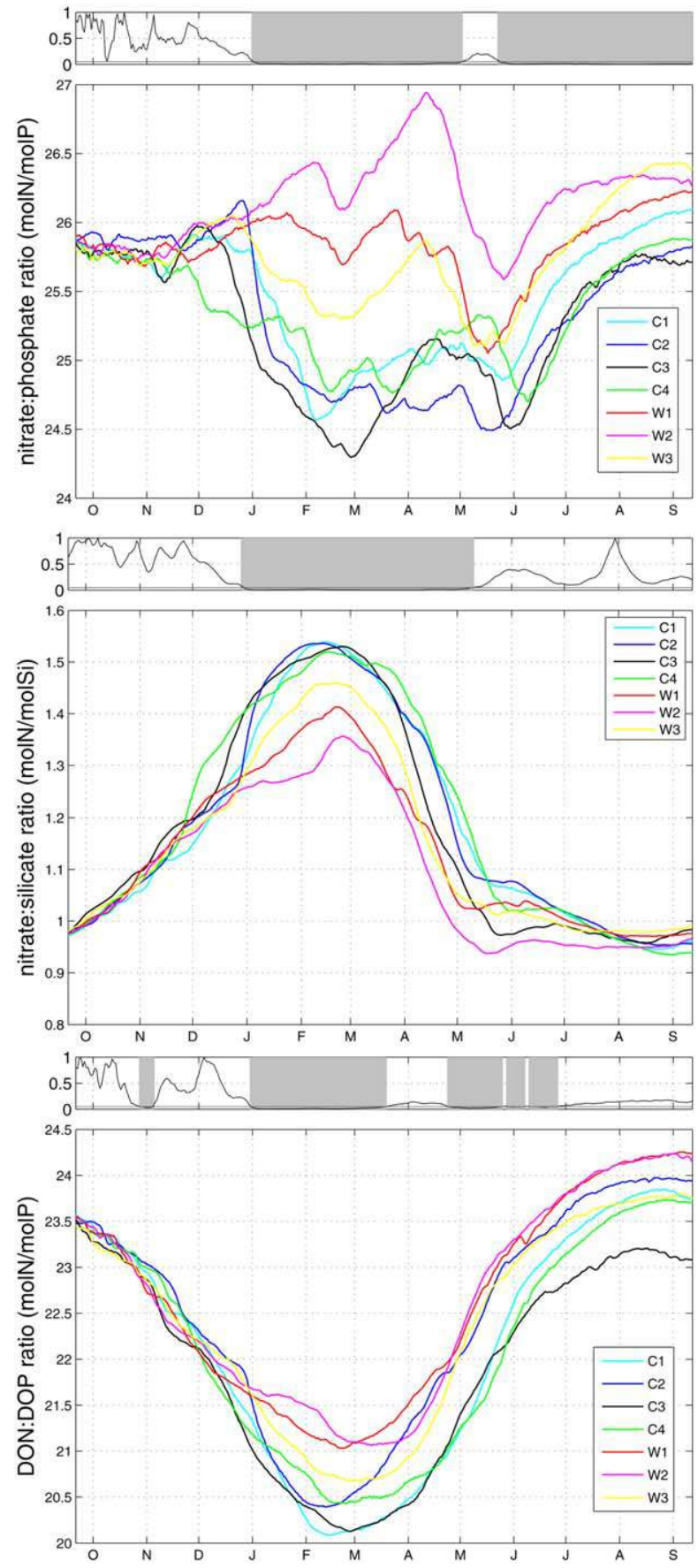

Figure 7. Time series for the seven annual simulations of the dissolved organic and inorganic matter averaged over the whole domain and over the first $200 \mathrm{~m}$ and of the associated $p$ value (see section 3.1): ratios between the concentrations of nitrate and phosphate, nitrate and silicate, and dissolved organic nitrogen and phosphorus. Periods of $p$ $<0.05$ highlighted in gray.

(Figure 6). Its maximum value $\left(\sim 0.5 \mathrm{mmolN} \mathrm{m}^{-3}\right)$ is reached between 30 and $50 \mathrm{~m}$ depth. These numbers are in agreement with the $0.3-0.5 \mathrm{mmolN} \mathrm{m}{ }^{-3}$ values observed by Diaz et al. [2001] between 20 and $60 \mathrm{~m}$ depth. Ammonium is then consumed by the phytoplankton and its concentration decreases then stabilizes. As for the other nutrients, the ammonium concentration interannual variability is weaker between July and December, and stronger between December and June. Differences between $\mathrm{C}$ and $\mathrm{W}$ groups are significant during this period and again, this variability is associated with the variability of winter convection, stronger mixing resulting in stronger ammonium depletion.

[29] The nitrate to phosphate ratio is generally higher than 20:1 in Mediterranean waters [Mc Gill, 1969], i.e.,
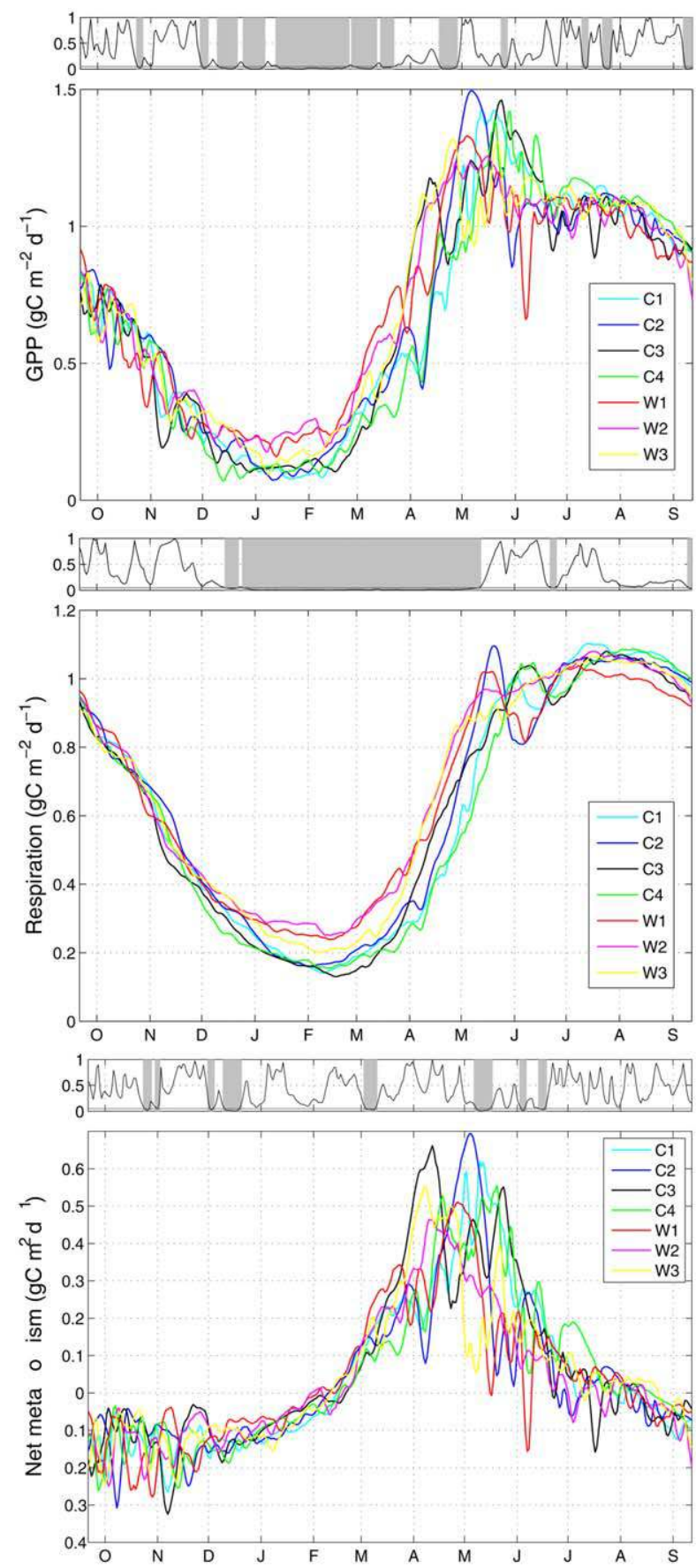

Figure 8. Time series for the seven annual simulations of the GPP, respiration and net metabolism averaged over the whole domain and of the associated $p$ value (see section 3.1). Periods of $p<0.05$ highlighted in gray. 

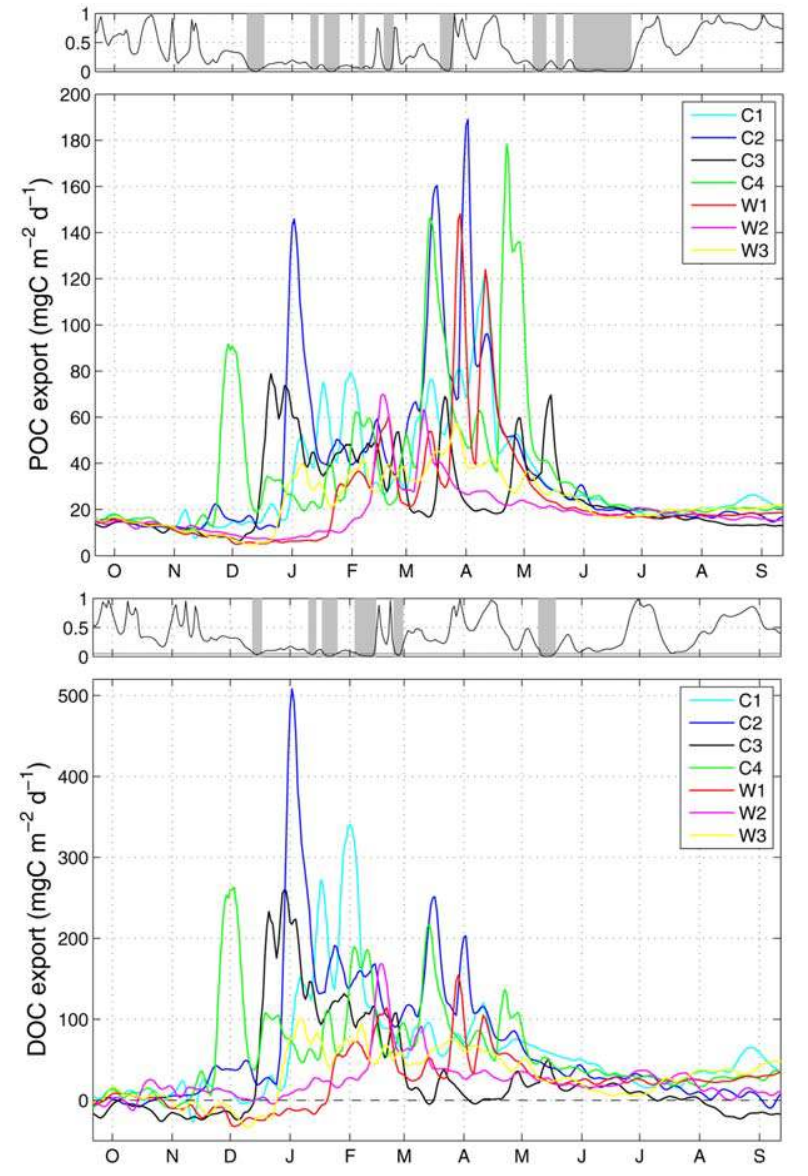

Figure 9. Time series for the seven annual simulations of the POC and DOC export under the $200 \mathrm{~m}$ isobath averaged over the whole domain and of the associated $p$ value. Periods of $p<0.05$ highlighted in gray.

than that of 16:1 measured in the Atlantic Ocean by Redfield et al. [1963]. This implies a trend of Mediterranean waters to be P-depleted relative to N [Krom et al., 1991; Thingstad and Rassoulzadegan, 1995; Diaz et al., 2001; Pinardi et al., 2006]. In our simulations, the nitrate:phosphate ratio, computed as the ratio of the spatially averaged concentrations of nitrate and phosphate, varies between 24:1 and 27:1 (Figure 7). This confirms that phosphorus availability may control the primary production in the NWMS at the scale of the basin. Maximum values and minimum interannual variability are obtained during the stratified period when nutrients availability is the weakest, suggesting that this control intensifies during this period. The interannual variability of the nitrate:phosphate ratio is larger during the winter mixing period. From January, the associated $p$ value remains lower than $5 \%$ during most of the year (Figure 7), winter oceanic and atmospheric conditions therefore induces significant and lasting differences of nitrate:phosphate ratio between years. Minimum values indicating a weaker phosphate depletion are obtained for years of strong convection during which the winter surface enrichment is larger. These seasonal evolution and interannual variability can be explained by the fact that the vertical nitrate concentration gradient is weaker than the phosphate concentration gradient: the ratio between the ni- trate concentration in the first $200 \mathrm{~m}$ and in the deep layer is $\sim 2$ whereas it is $\sim 2.5$ for the phosphate (Figures 3 and $6)$. The nitrate:phosphate ratio consequently decreases with depth. When convection occurs the nitrate:phosphate ratio of the resulting homogenized water mass is all the smaller that the convection is stronger. Such vertical gradients in bio-limiting nutrients usually result from a balance between phytoplankton demand in the euphotic layer, remineralization and organic matter export [e.g., Anderson et al., 2005]. But the difference in the gradient values is a special feature of Mediterranean Sea observed by Pujo-Pay et al. [2011] that is explained by a difference in the depths of phosphacline and nitracline, the first being deeper. This difference in depths may result from incomplete nitrate utilization by phytoplankton due to the lack of phosphate at the bottom of the euphotic layer [Diaz and Raimbault, 2000]. Our results therefore strengthens the hypothesis of a plankton origin to the high nitrate:phosphate ratios in the Mediterranean Sea and suggest that the convection physical process can partly alleviate the deficiency in phosphate relative to nitrate observed in the upper layer.

[30] Thingstad and Rassoulzadegan [1999] and Leblanc et al. [2003] observed that silicon can also be limiting in the NWMS, in particular after spring blooms, the nitrate to silicate ratio being larger than the $1: 1$ value given by Brzezinski [1985] for the global ocean. In our simulations, the nitrate:silicate ratio is minimum and approximately equal to $1: 1$ between June and September (Figure 7). Its interannual variability is very weak during this period. During the rest of the year the nitrate:silicate ratio is larger than $1: 1$ and reaches maximum values varying between 1.3 and 1.5 during the period of strong mixing. This result suggests a potential Si deficit compared to $\mathrm{N}$, in agreement with recent observations made in the whole Algero-Provencal basin by Crombet et al. [2011]. During the mixing period the interannual variability of the nitrate:silicate ratio is maximum, with larger values observed for years of strong convection. The $p$ values indicate that differences between years $\mathrm{C}$ and $\mathrm{W}$ are significant during this period and the following spring bloom (Figure 7). These seasonal evolution and interannual variability can be explained by the fact that the vertical nitrate concentration gradient is stronger than the silicate concentration gradient: the ratio between the silicate concentration in the first $200 \mathrm{~m}$ and in the deep layer is $\sim 1.5$ versus 2 for the nitrate (Figures 3 and 6). As a result, the nitrate to silicate ratio increases with depth. Thus the deeper convection is, the larger the nitrate:silicate ratio of the resulting homogenized water mass is. This suggests that the silicon availability may control the development of diatoms in the NWMS during winter convection, all the more that the convection is strong. This is clearly the case for year C2 (strong convection low microphytoplankton, Figures 4 and 6). However year $\mathrm{C} 3$ shows the opposite pattern, i.e., strong convection associated to large microphytoplankton biomass. Cullen et al. [2002] indeed showed that the development of large-sized phytoplankton can also be favored by strong turbulence and high nutrient concentrations. This is most probably due to the fact that the convection episode for $\mathrm{C} 3$ is very strong until the beginning of March but ends very soon compared with C1, C2, and C4 (Figure 4). As a result, the absolute silicate availability for C3 is the largest of the 7 years when the spring bloom 
begins in mid-March (Figure 6). Moreover, Herrmann et al. [2008a] showed that mesoscale structures that develop around the convection area transport stratified water inside the mixed region when the convection ends. This input of stratified water associated to smaller nitrate:silicate ratio would favor the decrease of this ratio. Indeed, at the end of May, when the microphytoplankton abundance is the largest for $\mathrm{C} 3$, the nitrate:silicate ratio is low compared to the other years (Figure 7). The development of microphytoplankton therefore appears to depend on a balance between the convection intensity and the duration of the convection episode that modulate the N:Si ratio of the upwelled water and the absolute nutrients availability.

\subsubsection{Phytoplankton}

[31] The seasonal evolution of phytoplankton is globally similar for the 7 years of the present period. The total chlorophyll concentration in the surface layer progressively decreases between September and January (Figure 6) due to the decrease in light availability associated with the deepening of the mixed layer (Figure 4). This concentration is minimum during winter convective mixing (JanuaryFebruary) with values around $0.1 \mathrm{mgChl} \mathrm{m}{ }^{-3}$ corresponding to observations made by Bosc et al. [2004] in February 1999 in the NWMS. Nano and microphytoplankton chlorophyll and carbon biomasses and total chlorophyll start to increase when the deep convection is maximum in winter (Figures 4 and 6) and not when deep convection ceases in spring, as observed by Marty et al. [2002]. This result is in agreement with the recent Dilution-Recoupling Hypothesis of Behrenfeld [2010]. In this hypothesis the initiation of bloom occurs owing especially to a decoupling between phytoplankton growth and grazing due to the vertical dilution of preys and predators by winter mixing. The winterto-spring distributions of zooplankton also tend to confirm that the prominence of the Behrenfeld [2010] hypothesis in driving the time occurrence of the bloom in the NWMS (see section 3.2.3). Chlorophyll concentration reaches its maximum in April-May, exceeding $1 \mathrm{mgChl} \mathrm{m} \mathrm{m}^{-3}$ in the Rhone plume and in the convection region in agreement with the maximum values observed by Bosc et al. [2004] in April 1999. This spring bloom however occurs approximately 1 month later than what was observed by Marty et al. [2002] at DYFAMED. The surface chlorophyll concentration decreases rapidly until June then more progressively. The initial spring chlorophyll concentration decrease seems mainly regulated by grazing more than by nutrient depletion: at this time of the year, zooplankton abundance and GPP are maximal (Figures 6 and 8). The surface layer depletion associated with the summer restratification (Figure 4) then also contributes to the lower chlorophyll concentration through the decrease of the GPP.

[32] The interannual variability of the total chlorophyll concentration is weak during the whole year, with a standard deviation of the annual average value equal to $5 \%$ (Table 3). This variability is larger during the winter mixing and spring bloom periods. Differences between $\mathrm{C}$ and W groups are however significant during the winter and beginning of spring and at the annual scale (Table 3). The interannual variability of chlorophyll concentration is associated both to the strength of winter convection and to the surface temperature: even if the surface enrichment during years of weak convection is smaller, euphotic layer is warmer. This favors the phytoplankton growth since the temperature influence on primary production is parameterized through an exponential Eppley-type term [Eppley, 1972], as explained in details in section 3.3.1. Larger values of chlorophyll concentration are therefore obtained for the three warm years. However the duration of the winter convection also influences the chlorophyll concentration: during C3, the convection is strong but ceases early, and though the surface layer is colder than the average, the chlorophyll concentration is larger. The evolution of $p$ values and large annual $p$ values obtained for annual pico and microphytoplankton show that the interannual variability of these groups is not directly related to the variability of winter atmospheric and oceanic conditions, contrary to what is obtained for nanophytoplankton.

[33] The spring bloom is mainly associated with a peak of nanophytoplankton and to a lesser extent of microphytoplankton (Figure 6). During the summer oligotrophic period, the picophytoplankton concentration progressively increases. The respective contributions of each phytoplankton group vary very weakly among the years, with standard deviation smaller than $2 \%$. We obtain a domination of the nanoplankton group that corresponds to observations. However, its contribution as well as the summer microphytoplankton concentration are overestimated in our simulations whereas the picophytoplankton and the spring microphytoplankton concentrations are underestimated: in our simulations, depending on the period, nanoplankton represents between 60 and $80 \%$ of the total chlorophyll biomass with a $80 \%$ average annual value, microplankton represents $10-30 \%$ with a $16 \%$ average annual value and picophytoplankton less than $10 \%$ with a $4 \%$ average annual value (Figure not shown). Observations by Marty et al. [2002], Marty and Chiaverini [2010], and Vidussi et al. [2000] suggest that the nanophytoplankton represents between 45 and $65 \%$ of the total chlorophyll biomass, that the microphytoplankton represents around 30\% in spring (versus $15 \%$ in our simulations) and $10 \%$ in summer (versus $20-25 \%$ in our simulations), and that the picophytoplankton contribution never goes below $10 \%$ and reaches $20 \%$ during the summer.

\subsubsection{Zooplankton}

[34] The three zooplankton groups follow globally the same seasonal evolution, similar for the 7 years (Figure 6). Zooplankton carbon concentration in the upper $200 \mathrm{~m}$ decreases between September and February, due to the decrease in preys availability and the dilution associated with vertical convective mixing. It reaches a minimum during the period and in the area of maximum convection. The zooplankton biomass increase begins several weeks after the initiation of the phytoplankton bloom when the availability of preys, less dispersed in the water column owing to the convection weakening, becomes sufficient. The delay varies from $\sim 3$ weeks for microzooplankton to $\sim 6$ weeks for mesozooplankton. This suggests that the convective process induces a temporal and spatial decoupling between the prey-predator system. This decoupling is reduced during the spring restratification period. These results are in line with the Dilution-Recoupling Hypothesis recently described by Behrenfeld [2010] that assumes that the bloom dynamic results from a balance between the phytoplankton growth and the zooplankton grazing and from the 
seasonally varying physical processes that affect this balance. The interannual variability of the three zooplankton groups is maximal during the winter convective mixing and spring bloom, then progressively decreases. The standard deviation of the annual zooplankton biomass is equal to $7 \%$ (Table 3), the larger concentrations being obtained for warm years, due to larger preys abundance and weaker vertical mixing. The evolution of $p$ values and the annual $p$ values obtained for each zooplankton group and for the whole zooplankton biomass (Figure 6 and Table 3) show that interannual variability of winter atmospheric and oceanic conditions induce differences on zooplankton abundance that stay significant most of the year and at the annual scale.

[35] Nanozooplankton consumes bacteria and picophytoplankton, whose concentrations are maximum in JulyAugust (Figure 6). Nanozooplankton carbon concentration is consequently maximum in summer. In 1999-2000, Tanaka and Rassoulzadegan [2002] observed at DYFAMED nanozooplankton concentrations varying between $0.02 \mathrm{mmolC} \mathrm{m}^{-3}$ in January and $0.2 \mathrm{mmolC} \mathrm{m}^{-3}$ in July in the 5-110 m layer. At this point, nanozooplankton concentration varies in our simulations between 0.05 and $0.3 \mathrm{mmolC} \mathrm{m} \mathrm{m}^{-3}$ in the $0-200 \mathrm{~m}$ layer, in agreement with those observations. Microzooplankton consumes mainly nanozooplankton, nanophytoplankton, and then microphytoplankton. Its maximum concentration is observed in end of May-June, it then remains high during the summer. At DYFAMED, its simulated concentration varies locally between 0.05 and $0.5 \mathrm{mmolC} \mathrm{m}^{-3}$ throughout the year, in agreement with values reported by Tanaka and Rassoulzadegan [2002]: 0.03 (January)-0.4 (May) mmolC $\mathrm{m}^{-3}$. Mesozooplankton consumes microzooplankton and microphytoplankton. It progressively increases after the winter minimum and reaches its maximum value in September. Concentration in the upper $200 \mathrm{~m}$ layer varies between 0.1 and $0.4 \mathrm{mmolC} \mathrm{m}^{-3}$. This temporal evolution is quantitatively in agreement with observations made by Gaudy and Champalbert [1998] off Marseilles: 0.05-0.3 mmolC m ${ }^{-3}$.

\subsubsection{Organic matter (DOM and POM)}

\subsubsection{Dissolved Organic Matter}

[36] DOC represents $77 \%$ of the total organic matter (Table 3). In our model, DOM is produced by messy feeding, phytoplankton exudation, POM remineralization and bacteria senescence (Figure 2). It is consumed by bacteria. As for the other components of the planktonic ecosystem (except ammonium), its concentration in the surface layer decreases between September and February-March (Figure 6). Taking into account the refractory DOM (40 mmolC m ${ }^{-3}$ for DOC, Santinelli et al. [2012] and 3 mmolN $\mathrm{m}^{-3}$ for DON, Pujo-Pay and Conan [2003]), the minimum modeled average concentrations of DOM in the surface layer vary in March around $45-50 \mathrm{mmolC} \mathrm{m}^{-3}$ and 3.9-4.5 mmolN m ${ }^{-3}$. Copin-Montégut and Avril [1993], Avril [2002], and Pujo-Pay and Conan [2003] observed minimum concentrations around $50-60 \mathrm{mmolC} \mathrm{m}^{-3}$ and 3.5 $\mathrm{mmolN} \mathrm{m}{ }^{-3}$. DOM concentration then increases due to the intensification of the microbial loop and the stratification of the water column. Maximum concentrations are reached in June-August for the DOC and in August-September for the DON and DOP. Locally, maximum modeled values can

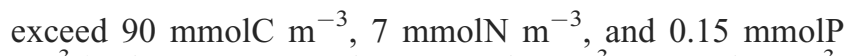
$\mathrm{m}^{-3}$ in the open sea and $150 \mathrm{mmolC} \mathrm{m}^{-3}, 8 \mathrm{mmolN} \mathrm{m}^{-3}$, and 0.18 mmolP $\mathrm{m}^{-3}$ over the shelf (Figures not shown). Copin-Montégut and Avril [1993], Avril [2002], and PujoPay and Conan [2003] observed maximum summer concentrations around $90-100 \mathrm{mmolC} \mathrm{m}^{-3}$ and $6 \mathrm{mmolN} \mathrm{m}^{-3}$ in the open Ligurian Sea. The modeled DON and DOC may thus be slightly overestimated probably owing to the bacterial biomass underestimation that may induce an underestimation of DOM assimilation (see section 3.2.5). The interannual variability of the DOM seasonal evolution and annual average is weak, it is however significant during the winter and spring and at the annual scales (Figure 6 and Table 3). Years and periods of stronger convection are associated with smaller DOM concentrations.

\subsubsection{Particulate Organic Matter}

[37] Large POM particles are produced by the mesozooplankton senescence. Small particles represent almost $100 \%$ of the total POM (Table 3) and are produced by zooplankton egestion and senescence and phytoplankton senescence. The evolution, variability, and $p$ values of large and small POM concentrations follow, respectively, those of mesozooplankton and nanophytoplankton (which largely dominates the total planktonic biomass (Table 3 and Figure 6)).

\subsubsection{Bacteria}

[38] Bacteria consumes DOM, they thus follow the same evolution (Figure 6). This seasonal evolution is in line with previous observations performed in the NWMS [Tanaka and Rassoulzadegan, 2002; Mével et al., 2008]. However the modeled bacteria biomasses are underestimated by a factor of 2-3 compared with those studies and recent in situ estimations [Christaki et al., 2011]. In our model, heterotrophic bacteria only absorb DOM. POM is remineralized into DOM via a parameterization independent from bacterial biomass. Thus, only free-living bacteria communities [sensu Mével et al., 2008] are taken into account. This modeling choice does not enable to account for the pool of particle-attached bacteria whose biogeochemical role in the POC cycling in the NWMS has been highlighted [Ghiglione et al., 2007]. Accounting for this pool of heterotrophic bacteria would partly reduce the bacteria biomass underestimation. Some underestimation of biogeochemical fluxes associated to bacteria activity and involved in the carbon cycle (organic matter consumption, respiration) may result from this bias (see sections 3.3.2 and 3.3.3).

[39] The interannual variability of the bacteria seasonal evolution is weak along the year (Figure 6) and on the annual mean (3\%, Table 3$)$. It is maximum and significant during the winter mixing and spring bloom periods. Differences of annual bacteria biomass between cold and warm years induced by interannual variability of winter atmospheric and oceanic conditions are significant, larger biomasses being associated with warm years.

[40] The evolution of the ratios of DON and DOP concentrations over the domain and the upper $200 \mathrm{~m}$ is shown on Figure 7. DOC:DON and DOC:DOP ratios are always larger than the bacteria internal composition ratios $C: N$ and $\mathrm{C}: \mathrm{P}$ (figures not shown), in particular during the stratified summer period. This suggests that nitrogen and phosphorus availability control the bacteria growth. Moreover the DON:DOP ratio is always larger than the bacteria 
internal composition ratio N:P (10.55), suggesting a stronger control by phosphorus availability. The control by phosphorus availability is influenced by the variability of winter atmospheric and oceanic conditions: the DON:DOP is larger for the stratified summer period and for "warm" years and the associated $p$ value is generally not significant.

\subsection{Interannual Variability of the Biogeochemical Processes}

[41] In this section, we examine the main biogeochemical processes in order to understand and characterize better the role of the NWMS pelagic planktonic ecosystem regarding the carbon cycle: primary production, dissolved inorganic carbon balance, and organic carbon deep export.

\subsubsection{Gross Primary Production GPP}

[42] The GPP corresponds to the fixation of dissolved inorganic carbon by the phytoplankton associated with the photosynthesis. It logically shows the same seasonal evolution and interannual variability as the phytoplankton carbon biomass (Figure 8). Minimum and maximum of NWMS averaged GPP values (respectively, $0.1-0.2 \mathrm{gC} \mathrm{m}^{-2} \mathrm{~d}^{-1}$ in February and $1.2-1.5 \mathrm{gC} \mathrm{m}^{-2} \mathrm{~d}^{-1}$ in April-May) are in good agreement with the $0.1-1.8 \mathrm{gC} \mathrm{m}^{-2} \mathrm{~d}^{-1}$ range measured by Marty and Chiaverini [2002]. In summer, the GPP slightly decreases from $\sim 1.0-1.2 \mathrm{gC} \mathrm{m}^{-2} \mathrm{~d}^{-1}$ in June to $\sim 0.8-1.1 \mathrm{gC} \mathrm{m}^{-2} \mathrm{~d}^{-1}$ in September, whereas values measured by Marty and Chiaverini [2002] decrease from $\sim 1.0$ to $\sim 0.5 \mathrm{gC} \mathrm{m}^{-2} \mathrm{~d}^{-1}$. This overestimation of the summer GPP in our model is related to the overestimation of the nanophytoplankton biomass during this period (see section 3.2.2).

[43] The annual GPP is in average equal to $250 \mathrm{gC} \mathrm{m}^{-2}$ $\mathrm{y}^{-1}$, with a very weak interannual variability $(3 \%$, Table 3). Marty and Chiaverini [2002] obtain annual GPP values varying between 86 and $232 \mathrm{gC} \mathrm{m}^{-2} \mathrm{y}^{-1}$. Note however that their estimations are based on instantaneous GPP measurements made at a monthly frequency, whose relevance could be questionable given the high GPP daily variability (Figure 8). The winter GPP shows a stronger variability (the standard deviation of the average December-February GPP is equal to $23 \%$ ) and is responsible for the annual variability: the correlation coefficient between the average December-February GPP and the annual GPP is equal to 0.90 ( $\mathrm{SL}>0.9999)$. This variability is mainly related to the strength of the winter convection, and contrary to what could be expected at first sight, years with stronger mixing are related to lower GPP and chlorophyll accumulation (section 3.2.2) than warmer years with less mixing: we obtain a -0.82 (SL $>0.9999)$ correlation coefficient between the annual GPP and the annual $\mathrm{MLD}_{N W M S}$. Moreover these differences between warm and cold years are significant, as shown by the $p$ values in winter and at the annual scale. They can be explained first by the fact that vertical displacements associated with deep convection prevent the phytoplankton from staying at the lighted surface layer and thus from developing through photosynthesis. Second, deep convection is also associated with surface cooling (see section 3.1), and GPP depends on the water temperature. This dependency on the water temperature is taken into account through the Eppley [1972] type parameterization that involves the term $f(T)=Q_{10}^{\frac{T-T_{1}}{T_{2}}}$ in the GPP equation, with $Q_{10}=$
$2.0, T_{1}=20^{\circ} \mathrm{C}, T 2=10^{\circ} \mathrm{C} \quad[$ Herrmann, 2007; Auger et al., 2011]. All other factors being equal, a temperature difference of $\Delta T=+0.33^{\circ} \mathrm{C}$ (the variability of the upper $200 \mathrm{~m}$ temperature, Table 3 ) would induce a relative GPP difference of $1-Q_{10}^{\frac{\Delta T}{T 2}}=+2.3 \%$. This value is of the same order as the $3 \%$ variability computed for the average GPP (Table 3). Our results therefore suggest that the warmer and more stable mixed layer associated with weaker convection has a positive impact on the phytoplankton development that counteracts the negative impact of the smaller nutrient availability.

\subsubsection{Respiration and Net Metabolism}

[44] The cumulated respiration (autotroph + heterotrophic) corresponds to the remineralization of organic carbon under the dissolved inorganic carbon form by the planktonic ecosystem. The difference between GPP and respiration is equal to the net balance of dissolved inorganic carbon fixation or production: the net metabolism [Smith and Hollibaugh, 1993]. The evolution of GPP, total respiration and net metabolism is showed on Figure 8 . The seasonal evolution of respiration follows the evolution of GPP, with a very weak interannual variability all along the year and in average (4\%, Table 3$)$. Seventy-one percent of the annual total respiration is due to the bacteria respiration. This contribution is almost constant among the years (interannual variability $<1 \%$ ). Periods and years of high respiration therefore correspond to periods of strong bacterial activity. As for the GPP, differences between cold and warm years are significant during winter and beginning of spring and on the annual averages, with warmer years associated to stronger respiration.

[45] Between August and February, the net metabolism is negative, the NWMS planktonic ecosystem acts as a source of dissolved inorganic carbon. During the rest of the year, autotroph processes dominate those of the heterotrophic community, the NWMS acts as a sink of dissolved inorganic carbon regarding the soft-tissue biological pump. In average, the annual net metabolism is equal to $16 \mathrm{gC} \mathrm{m}^{-2} \mathrm{y}^{-1}$ and is positive for the 7 years (Table 3). Annually, the NWMS therefore always acts as a sink for the dissolved inorganic carbon regarding the pelagic planktonic ecosystem, in agreement with conclusions of Sempéré et al. [2000]. The interannual variability of the annual net metabolism is large, equal to $22 \%$. However the evolution and the annual mean of the $p$ values show that differences between $\mathrm{C}$ and $\mathrm{W}$ years are not significant, and the correlation coefficient between the annual $\mathrm{MLD}_{N W M S}$ and the annual net metabolism is equal to 0.61 $(\mathrm{SL}>0.85)$. This suggests that the winter heat flux and the oceanic convection are not the major factors responsible for this interannual variability. In fact, the net metabolism is strongly related to the annual $T_{N W M S}$, with a correlation coefficient equal to -0.91 ( $\mathrm{SL}>00.9999)$ : the net metabolism is smaller during the warm years. This is mostly due to the fact that the bacterial activity, hence respiration, is particularly strong those years (see section 3.2.5). Note that the underestimation of the modeled bacteria biomass (see section 3.2.5) likely induces an underestimation of the intensity of heterotrophic processes, in particular of bacterial respiration. The annual net metabolism may thus be overestimated, and the NWMS may be a lower sink for dissolved inorganic carbon than suggested by the model outputs. 


\subsubsection{Organic Carbon Bottom Export}

[46] The vertical export of organic carbon is estimated by computing the sum of the net sedimentation, advection, and diffusion fluxes across the $200 \mathrm{~m}$ isobath. The POC export takes into account particulate organic carbon, phytoplankton, zooplankton, and bacteria. The evolution of the DOC and POC export is shown in Figure 9. For both dissolved and particulate compartments, organic carbon export is clearly associated with deep convection: it is strong during the winter mixing period (mid-November to mid-May) and much lower during the stratified JuneNovember period. This behavior was observed by Avril [2002] at DYFAMED for the DOC export. Annually, the DOC export varies between 8.5 and $24.5 \mathrm{gC} \mathrm{m}^{-2} \mathrm{y}^{-1}$, and the POC export between 7.0 and $13.6 \mathrm{gC} \mathrm{m}^{-2} \mathrm{y}^{-1}$ (Table 3). At DYFAMED, Copin-Montégut and Avril [1993] and Avril [2002] measured values of DOC export varying between 13 and $22 \mathrm{gC} \mathrm{m}^{-2} \mathrm{y}^{-1}$, and Miquel et al. [1992] and Marty et al. [1994] measured values of POC export varying between 4 and $7 \mathrm{gC} \mathrm{m}^{-2} \mathrm{y}^{-1}$. The ranges given by the model are therefore in good agreement with the available observations. The DOC export may however be slightly overestimated due to the underestimation of the bacteria biomass (section 3.2.5) but available data do not allow to evaluate that more precisely.

[47] The interannual variability of the annual organic carbon export is large (37\%, Table 3). Deep convection appears to be one of the main factor of organic carbon deep export: we obtain correlation coefficients of $\sim 0.74$ (SL $>98 \%$ ) between the annual exports of POC, DOC and total organic carbon and the annual $\mathrm{MLD}_{N W M S}$. Differences between group $\mathrm{C}$ and group $\mathrm{W}$ are significant $(p<5 \%$, see Table 3). Export is more than twice larger during " $\mathrm{C}$ " years than during "W" years. This difference can be attributed to the vertical displacements that occur throughout the water column during deep convection: as they do for dense water formed at the surface, they transport organic matter produced in the euphotic surface layer down to the deep ocean. The stronger convection is, the stronger these displacements, hence organic carbon exports are. Deep convection intensity is itself strongly correlated to the winter surface heat loss (see section 3.1). This shows that the atmospheric interannual variability, precisely the interannual variability of winter heat loss, strongly determines the variability of organic carbon export toward the deep ocean, hence plays a key role in the Mediterranean carbon cycle. During warm years associated with weak winter heat loss and convection, organic carbon is less exported and may moreover be remineralized within the upper water column. This would still weaken the ocean carbon storage since the resulting carbon dioxide would be not sequestered in the Mediterranean deep waters.

[48] Furthermore, there are some quantitative differences in the form of carbon export depending on the warm or cold year type. The interannual variability of annual average export is larger for DOC export than for POC: there is a factor of 1.9 between the standard deviation of, respectively, DOC and POC exports, and the relative difference between $\mathrm{C}$ and $\mathrm{W}$ years is 1.4 times larger for DOC than for POC. Hence the convection intensity would favor the export of organic carbon under the dissolved form. Some observations [see review of Santinelli et al., 2012] show high values of DOC concentrations at depths $>1500 \mathrm{~m}$ in the Algero-Provencal Basin following episode of intense shelf or open ocean convection [Canals et al., 2007]. The amount of DOC exported at depth mainly depends on the amount of deep water formed but also on the ecosystem activity that control surface DOC concentrations through production and consumption processes. The model reproduces the surface DOC accumulation during the stratified period (Figure 6). This feature already observed in the oligotrophic Mediterranean Sea has been attributed to the lack of phosphorus during summer that limits the bacteria DOC consumption [Moutin et al., 2002]. According to the observations the exported DOC is very quickly consumed and remineralized to $\mathrm{CO}_{2}$ by heterotrophic bacteria as attested by high Apparent Oxygen Utilization at depth and the disappearance of the signal of high concentrations in a few months [Santinelli et al., 2012]. The interannual variability of the deep DOC export may have some implications for the activity and diversity of deep water microbial loop [e.g., Magagnini et al., 2007; Martin-Cuadrado et al., 2007]. In particular, the DOC remineralization rates and the occurrence of different microbial communities are higher in the Mediterranean deep water than in the global deep ocean.

[49] In average, $25.5 \mathrm{gC} \mathrm{m}^{-2} \mathrm{y}^{-1}$ of organic carbon is exported annually towards the sea bottom (Table 3 ). This represents $\sim 10 \%$ of the annual GPP (the e-ratio). The other $90 \%$ will then be remineralized within the euphotic layer. This suggests that the GPP would mainly be associated with regenerated production at the scale of the NWMS. The interannual variability of the e-ratio is equal to $4 \%$ (Table 3). This weak variability is associated with the convection strength, with a 0.75 correlation coefficient (SL $>0.9999)$ between the e-ratio and the annual MLD $_{N W M S}$ and a small $p$ value: the e-ratio is larger during more convective years, suggesting that the contribution of new production would be slightly stronger those years.

\section{Discussions and Conclusions}

[50] We developed and used a 3-D coupled physicalbiogeochemical model and performed a groups of seven simulations under the XXth century climate conditions in order to assess the effect of oceanic and atmospheric interannual variability on the NWMS pelagic planktonic ecosystem, in terms of functioning, seasonal evolution and carbon cycle. The objectives of the paper were to study this area as a whole since it can be considered as homogeneous and highly productive at the scale of the Mediterranean basin. For that we performed statistical and budget analysis of the model results.

[51] First, our results show that the model reproduces correctly and quantitatively the seasonal and spatial variability and the main characteristics of the biogeochemical components and processes of this ecosystem. They support the Dilution-Recoupling Hypothesis of Behrenfeld [2010] and are in line with some recurrent observations of phytoplankton spring blooms in the apparent absence of water column stratification [e.g., Townsend et al., 1992; Backhaus et al., 1999; Körtzinger et al., 2008]: the spring bloom initiation seems to be induced by the decoupling between preys and predators that allows the loss term 
(grazing) to be smaller than the gain term (growth), rather than by the decrease of the mixed layer depth. The e-ratio analysis suggests that regenerated primary production may represent most of the total GPP at the scale of the NWMS. This dominance of regenerated production characterizes oligotrophic regimes. Note however that in summer, i.e., the period during which the contribution of the regenerated production is stronger, the GPP is overestimated in our simulations due to the nanophytoplankton overestimation. The contribution of the regenerated production to the total GPP may therefore be weaker than what is obtained here. Our model also reproduces and confirms a biogeochemical specificity of this ecosystem demonstrated experimentally by Thingstad et al. [1998] and Tanaka et al. [2003]: the weak phosphorus availability during stratified conditions controls both the phytoplankton development and the bacteria growth, inducing a competition among those groups for this element uptake. This control seems to be a permanent characteristic of the planktonic pelagic ecosystem in average over the NWMS. Note however that the analysis of the N:P ratio time and depth evolutions shows that it varies strongly throughout the water column (figure not shown), with minimum and maximum values reaching, respectively, 5 and 40, as observed by Marty et al. [2002]. It also confirms their observation that nitrate could be a limiting nutrient in autumn for very shallow $(<40 \mathrm{~m})$ waters of weak chlorophyll concentrations and suggests that this is also the case in summer.

[52] We identified three main weaknesses of our model. First the relative contribution of nanophytoplankton to the total phytoplanktonic biomass and GPP is however overestimated, and the contribution of each phytoplankton group should be improved. This is probably due to the choice of the parameters involved in the GPP formulation (in particular the Chl-specific absorption coefficient, the maximum quantum yield, and the terms involved in the Eppley type parameterization, see Herrmann [2007] and Auger et al. [2011]). To adjust them it will be necessary to perform sensitivity studies to these parameters, initially chosen from empirical information available in the literature. The formulation of other biological processes involved in the phytoplankton concentration equilibrium (grazing, senescence... ) may also need to be tested. Second, the spring bloom occurs in our simulations with approximately one month delay. Improving the realism of the phytoplankton size classes composition should also reduce this bias: Marty et al. [2002] observed that this bloom is largely associated with microphytoplankton, whose contribution is underestimated in our model. Third, the bacteria biomass is significantly underestimated, which could be partly corrected by including the particle-attached bacterial pool in the bacteria component.

[53] Aware of the weaknesses and strengths of our model, we used it to examine the interannual variability of the NWMS pelagic planktonic ecosystem, considering the area as whole. First, our results suggest that deep convection influences the $\mathrm{N}: \mathrm{P}$ and $\mathrm{N}: \mathrm{Si}$ ratios in the euphotic layer because of the differences of nitrate, phosphate, and silicate vertical gradients. The depletion in phosphate relative to nitrate could be temporally reduced during the period and for the years of strong convection. Deep convection may also control the microphytoplankton devel-

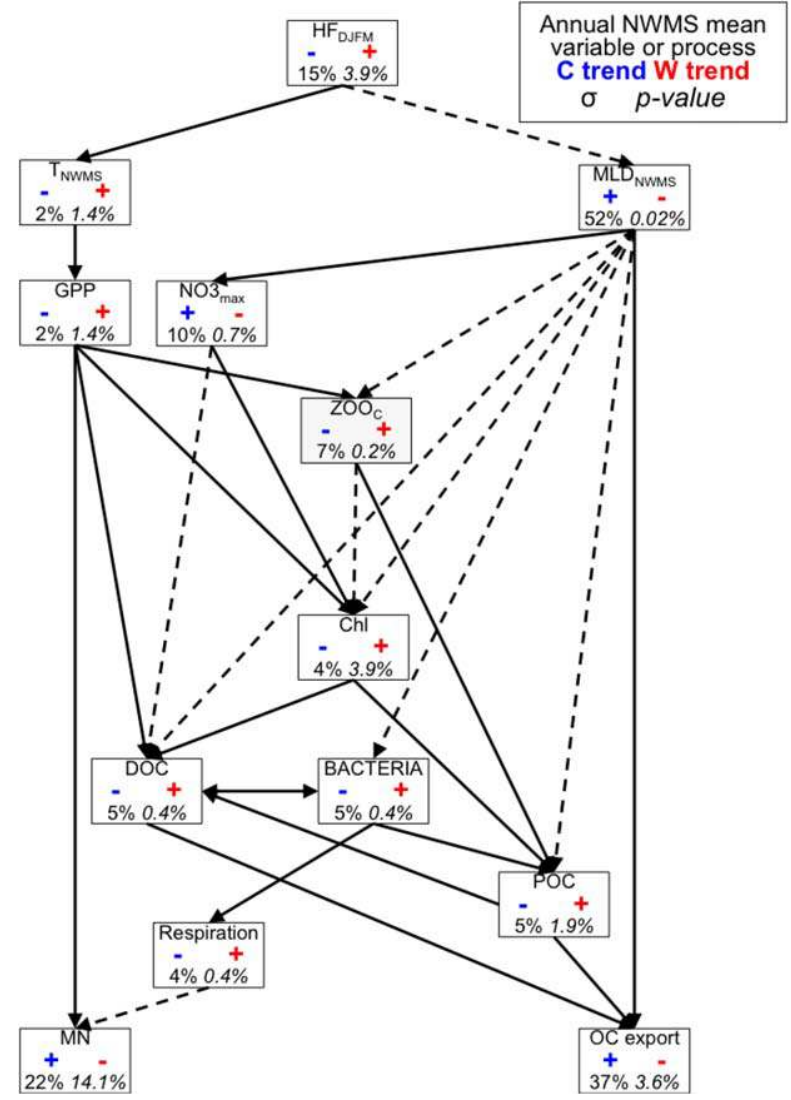

Figure 10. Synthetic scheme presenting the effect of interannual variability of winter atmospheric conditions on the NWMS ecosystem at the scale of the basin. Blue and red signs indicates the trend associated with the respectively $\mathrm{C}$ or $\mathrm{W}$ type years. Standard deviations among the seven annual averages of the given variable or process averaged annually and over the whole NWMS and associated $p$ values are indicated below. Solid and dotted lines indicate the respectively positive and negative relationships between variables and/or processes.

opment through the influence of its intensity and timing on the absolute nutrients availability and its negative impact on the $\mathrm{N}$ : Si ratio.

[54] Second, we show that the variability of atmospheric and hydrodynamic processes, namely the winter atmospheric heat loss and the resulting oceanic convection, induces differences on the NWMS averaged biogeochemical variables and processes through a chain of relationships that add up to or counteract each others. At the annual scale, those differences are most of the time significant. Figure 10 presents a synthetic scheme of those relationships. Originally the interannual variability of winter atmospheric heat loss induces differences of surface layer temperature and vertical mixing, which are, respectively, colder and deeper when the heat loss is stronger. Colder surface layer results in smaller GPP. Stronger mixing results in larger nutrients availability and larger dilution of organic biogeochemical stocks (heterotrophic and autotrophic planktons, dissolved and particulate organic matter). Smaller GPP and stronger dilution both hinders zooplankton growth. For the phytoplankton groups, the negative 
impact of smaller GPP and stronger dilution counteracts the positive effect of larger nutrient availability and weaker zooplankton grazing. This compensating effect explains that differences between cold and warm years are less significant for these groups biomasses than for other variables for which impacts add up to each other (Table 3 and Figure 6). Smaller GPP associated with larger nutrient availability results in smaller phytoplankton exudation that, together with stronger dilution, reduces DOM abundances. Stronger dilution and smaller DOM abundances then hinders bacteria growth. Zooplankton, phytoplankton, and bacteria smaller abundance as well as stronger dilution result in smaller POM abundance. Interannual variability of winter oceanic and atmospheric conditions hence results in significant differences of all the pelagic ecosystem components at the annual scale, colder winters being associated with smaller annual organic biomasses. Smaller bacteria biomass results in weaker respiration: $3 / 4$ of the annual respiration is due to the bacteria respiration that mainly occurs in summer when the microbial loop is very active, in particular during warm years. Smaller GPP and respiration, that show weak interannual variabilities (3-4\%), compensate each other: the interannual variability of the net metabolism, though large $(22 \%)$, is not related to the winter conditions. It is rather negatively related to the surface layer temperature. The absence of correlation with the convection strength together with the correlation with water temperature can be explained by the fact that water temperature results from the winter but also the summer atmospheric conditions. This suggests that the large net metabolism interannual variability may rather be related to summer physical processes, in particular summer heat flux. The net metabolism is always positive with a mean value of $16 \mathrm{gC} \mathrm{m}^{-2} \mathrm{y}^{-1}$. These results suggest that the NWMS pelagic ecosystem systematically acts as a sink for the dissolved inorganic carbon, all the more that the water is cold in summer. Concerning the deep organic carbon export, the positive effect of stronger mixing is stronger that the counteracting negative effect of smaller particulate organic matter abundance. Deep carbon export shows a strong interannual variability (37\%) that is significantly related to winter oceanic and atmospheric conditions, and also remains always positive: the NWMS acts as a sink for organic carbon all the more than the winter mixing is strong. For most of the variables and processes, the initial differences induced by the interannual variability of winter atmospheric and oceanic conditions are larger and significant during the periods of winter vertical mixing. Our results however suggest that these differences can stay significant, though weaker, during the following spring and even summer and autumn seasons and at the annual scale. Conditions of a given winter could therefore influence the composition of the ecosystem at the beginning of the following winter. This could possibly play a role in the interannual variability of the NWMS ecosystem.

[55] For most of the biogeochemical variables the modeled interannual variability is significant but not very high (varying between 4 and 14\%, Table 3 ). One of the main reasons for that is the smoothing effect of our budget diagnostics: the spatial averaging first filters out the small-scale spatial variability along vertical and horizontal dimensions. This variability can be very strong, both on the horizontal scale as can be seen for example by Figure 1 and on the vertical scale (see the above example of the nitrate:phosphate ratio). Depending on the spatial extension and on the position of deep convection, a given point could for example belong to the convective area some years and not others. Variables at this point would therefore show a strong interannual variability that would be partly filtered out by the integrating effect of the space averaging. The NWMS moreover includes regions submitted to the influence of different physical processes (coastal and shelf dynamics, Northern current, open ocean convection, river plumes, mesoscale activity, etc.). The time averaging then similarly filters the high frequency, which is strong for some variables or processes (see, e.g., GPP, Figure 8). For the same reason, it is very difficult to evaluate the interannual variability of the NWMS ecosystem components and process at the basin scale from observations. Long time series of observations are indeed punctual and at a rather low frequency. For example comparing observations made at the DYFAMED station at a monthly frequency [Marty and Chiaverini, 2010] suggests at the first sight that our model underestimates the GPP interannual variability, however given the frequency of this punctual time series the relevance of the comparison is questionable. Finally, the interannual variability of biogeochemical stocks and processes over the NWMS is not very well known. This highlights one of the main interests of 3-D coupled modeling: by providing a description of the ecosystem that is not perfect but continuous along the four dimensions, it allows to study the functioning, variability and role of the NWMS ecosystem as a whole. It therefore appears as a valuable tool to complement spatially or temporally punctual observations that can not represent thoroughly all the scales of variability of this ecosystem.

[56] In addition to the necessary improvement mentioned above, other sources of errors and uncertainties of our modeling approach should be investigated, as the impact of the physical parameterizations and the formulation of the biogeochemical boundary conditions. This last point should be considerably improved thanks to current coupled modeling projects developed at the Mediterranean scale (SIMED2, MEDICCBIO). Next improvements concern also the implementation of an alkalinity module and the coupling with benthic ecosystems and sediment transport models. Ultimately, our approach tends to develop a regional earth system model that would represent the different physical and biological compartments of the NWMS system and their interactions. This tool will be used to study many open scientific questions concerning the functioning, variability and evolution of the NWMS system. The present paper, that considers the NWMS as a whole and assesses the impact of the oceanic and atmospheric interannual variability on its pelagic planktonic ecosystem and associated carbon cycle under present climate conditions, constitutes the first step of a longer term work. Following this study, we then used our 3-D hydrodynamical-biogeochemical coupled model to perform a first study of the potential impact of climate change on this ecosystem (Herrmann et al., Impact of climate change on the Northwestern Mediterranean Sea pelagic planktonic ecosystem and associated carbon cycle, submitted to Journal of Geophysical Research, 2013). Our simulations also showed that there is a strong spatial 
variability inside our domain (shelf region, deep convection region, Northern Current region..., Figure 5). Next steps of our work focus on this spatial variability (e.g., over the Gulf of Lion shelf and in the Rhone river plume) [Auger et al., 2011]. Moreover our study aimed to explore the interannual variability of the ecosystem from a statistical and budget point of view. P. A. Auger et al. (2013, Interannual control of plankton communities by deep winter mixing and prey/predator interactions in the NW Mediterranean, Results from a 30-year 3D modelling study, in revision at Progress in Oceanography) explore in details the variability modes of this ecosystem.

[57] Acknowledgment. This work was partly funded by the SESAME project (contract GOCE-2006-036949) from the sixth Framework Program of the European Commission.

\section{References}

Anderson, T., D. Hessen, J. Elser, and J. Urabe (2005), Metabolic stoichiometry and the fate of excess carbon and nutrients in consumers, $\mathrm{Am}$ Nat., 165, 1-15.

Anderson, T. R., and P. Pondaven (2003), Non-redfield carbon and nitrogen cycling in the Sargasso Sea: Pelagic imbalances and export flux, Deep Sea Res., Part I, 50, 573-591.

Antoine, D., A. Morel, and J.-M. André (1995), Algal pigment distribution and primary production in the Eastern Mediterranean as derived from coastal zone color scanner observations, J. Geophys. Res., 100, 16,19316,209 .

Auclair, F., C. Estournel, P. Marsaleix, and I. Pairaud (2006), On coastal ocean embedded modeling, Geophys. Res. Lett., 33, L14602, doi: 10.1029/2006GL026099.

Auger, P., F. Diaz, C. Ulses, C. Estournel, J. Neveux, F. Joux, M. Pujo-Pay, and J. Naudin (2011), Functioning of the planktonic ecosystem of the Rhone river plume (NW Mediterranean) during spring and its impact on the carbon export: A field data and 3-D modelling combined approach, Biogeosciences, 8, 3231-3261, doi:10.5194/bg-8-3231-2011.

Avril, B. (2002), DOC dynamics in the Northwestern Mediterranean Sea (DyFaMed site), Deep Sea Res., Part II, 49, 2163-2182.

Backhaus, J., H. Wehde, E. N. Hegseth, and J. Kampf (1999), Phytoconvection-on the role of oceanic convection in primary production, Mar. Ecol. Prog. Ser., 189, 77-92.

Baklouti, M., F. Diaz, C. Pinazo, V. Faure, and B. Quéguiner (2006a), Investigation of mechanistic formulations depicting phytoplankton dynamics for models of marine pelagic ecosystems and description of a new model, Prog. Oceanogr., 71(1), 1-33.

Baklouti, M., V. Faure, L. Pawlowski, and A. Sciandra (2006b), Investigation and sensitivity analysis of a mechanistic phytoplankton model implemented in a new modular numerical tool (Eco3M) dedicated to biogeochemical modelling, Prog. Oceanogr., 71(1), 34-58.

Behrenfeld, M. (2010), Abandoning Sverdrup's Critical Depth Hypothesis on phytoplankton blooms, Ecology, 91(4), 977-989.

Béranger, K., Y. Drillet, M.-N. Houssais, P. Testor, R. Bourdallé-Badie, B. Alhammoud, A. Bozec, L. Mortier, P. Bouruet-Aubertot, and M. Crépon (2010), Impact of the spatial distribution of the atmospheric forcing on water mass formation in the Mediterranean Sea, J. Geophys. Res., 115, C12041, doi:10.1029/2009JC005648.

Berline, L., et al. (2012), Comparison of six Mediterranean zooplankton time series, Prog. Oceanogr., 97-100, 76-91.

Béthoux, J.-P., P. Morin, C. Madec, and B. Gentili (1992), Phosphorus and nitrogen behaviour in the Mediterranean Sea, Deep Sea Res., Part A, 39(9), 1641-1654.

Béthoux, J.-P., B. Gentili, P. Morin, E. Nicolas, C. Pierre, and D. Ruiz-Pino (1999), The Mediterranean Sea: A miniature ocean for climatic and environmental studies and a key for the climatic functioning of the North Atlantic, Prog. Oceanogr., 44, 131-146.

Bosc, E., A. Bricaud, and D. Antoine (2004), Seasonal and interannual variability in algal biomass and primary production in the Mediterranean Sea, as derived from 4 years of SeaWifs observations, Global Biogeochem. Cycles, 18, GB1005, doi:10.1029/2003GB002034.

Brzezinski, M. A. (1985), The Si:C:N ratios of marine diatoms: Interspecific variability and the effect of some environmental variables, J. Phycol., 21, 345-357.
Butenschön, M., M. Zavatarelli, and M. Vichi (2012), Sensitivity of a marine coupled physical biogeochemical model to time resolution, integration scheme and time splitting method, Ocean Modell., 52-53, 36-53, doi:10.1016/j.ocemod.2012.04.008.

Canals, M., P. Puig, X. Durrieu de Madron, S. Heussner, A. Palanques, and J. Fabres (2007), Flushing submarine canyons, Nature, 444, 354-357.

Caron, D., H. Dam, P. Kremer, E. Lessard, L. Madin, T. Malone, J. Napp, E. Peele, M. Roman, and M. Youngbluth (1995), The contribution of microorganisms to particulate carbon and nitrogen in surface waters of the Sargasso Sea near Bermuda, Deep Sea Res., Part I, 42, 943-972.

Christaki, U., et al. (2011), Microbial food webs and metabolic state across oligotrophic waters of the Mediterranean Sea during summer, Biogeosci. Discuss., 8, 1839-1852.

Christensen, J., T. Carter, and F. Giorgi (2002), PRUDENCE employs new methods to assess European climate change, Eos Trans. AGU, 83(13), 147.

Copin-Montégut, G., and B. Avril (1993), Vertical distribution and temporal variation of dissolved organic carbon in the north-western Mediterranean Sea, Deep Sea Res., Part I, 40(10), 1963-1972.

Crispi, G., A. Crise, and C. Solidoro (1998), Three-dimensional oligotrophic ecosystem models driven by physical forcings: The Mediterranean Sea case, Environ. Modell. Software, 13, 483-490.

Crispi, G., A. Crise, and E. Mauri (1999), Seasonal three-dimensional study of the nitrogen cycle in the Mediterranean Sea. Part II: Verification of the energy constrained trophic model, J. Mar. Syst., 20, 357-380.

Crispi, G., A. Crise, and C. Solidoro (2002), Coupled Mediterranean ecomodel of the phosphorus and nitrogen cycles, J. Mar. Syst., 33-34, 497521.

Crombet, Y., K. Leblanc, B. Queguiner, T. Moutin, P. Rimmelin, J. Ras, H. Claustre, N. Leblond, L. Oriol, and M. Pujo-Pay (2011), Deep silicon maxima in the stratified oligotrophic Mediterranean Sea, Biogeosciences, 8, 459-475.

Cullen, J., P. Franks, D. Karl, and A. Longhurst (2002), Physical influences on marine ecosystem dynamics, in The Sea, vol. 12, edited by A. R. Robinson et al., pp. 297-335, Harvard Univ. Press, Cambridge, Mass.

Diaz, F., and P. Raimbault (2000), Nitrogen regeneration and dissolved organic nitrogen release during spring in a NW Mediterranean coastal zone (Gulf of Lions): Implications for the estimation of new production, Mar. Ecol. Prog. Ser., 197, 53-66.

Diaz, F., P. Raimbault, and P. Conan (2000), Small-scale study of primary productivity during spring in a Mediterraean coastal area (Gulf of Lions), Cont. Shelf Res., 20, 975-996.

Diaz, F., P. Raimbault, B. Boudjellal, N. Garcia, and T. Moutin (2001), Early spring phosphorus limitation of primary productivity in a NW Mediterranean coastal zone (Gulf of Lions), Mar. Ecol. Prog. Ser., 211, 51-62.

D'Ortenzio, F., and M. Ribera d'Alcalà (2009), On the trophic regimes of the Mediterranean Sea: A satellite analysis, Biogeosciences, 6, 139-148.

D’Ortenzio, F., D. Iudicone, C. de Boyer Montegut, P. Testor, D. Antoine, S. Marullo, R. Santoleri, and G. Madec (2005), Seasonal variability of the mixed layer depth in the Mediterranean Sea as derived from in situ profiles, Geophys. Res. Lett., 32, L12605, doi:10.1029/2005GL022463.

Dugdale, R., and F. Wilkerson (1988), Nutrient sources and primary production in the eastern Mediterranean, Oceanol. Acta, 9, 179-184.

Eppley, R. (1972), Temperature and phytoplankton growth in sea, Fish. Bull., 70, 1063-1085.

Estournel, C., F. Auclair, M. Lux, C. Nguyen, and P. Marsaleix (2009), Scale oriented embedded modeling of the North-Western Mediterranean in the frame of MFSTEP, Ocean Sci., 5, 73-90.

Fontana, C., C. Grenz, C. Pinazo, P. Marsaleix, and F. Diaz (2009), Assimilation of SeaWiFS chlorophyll data into a 3D coupled physical biogeochemical model applied to a freshwater influenced coastal zone, Cont. Shelf Res., 29(11-12), 1397-1409.

Fukuda, R., H. Ogawa, T. Nagata, and I. Koike (1998), Direct determination of carbon and nitrogen contents of natural bacterial assemblages in marine environments, Appl. Envir. Microbiol., 64, 3352-3358.

Garcia-Comas, C., L. Stemmann, F. Ibanez, L. Berline, M. Mazzocchi, S. Gasparini, M. Picheral, and G. Gorsky (2011), Zooplankton long-term changes in the NW Mediterranean Sea: Decadal periodicity forced by winter hydrographic conditions related to large-scale atmospheric changes?, J. Mar. Syst., 87, 216-226.

Gaspar, P., Y. Gregoris, and J. Lefèvre (1990), A simple eddy kinetic energy model for simulations of the oceanic vertical mixing: Tests at station Papa and long-term upper ocean study site, J. Geophys. Res., 95, 16,179-16,193. 
Gaudy, R., and G. Champalbert (1998), Space and time variations in zooplankton distribution south off Marseilles, Oceanol. Acta, 21(6), 793802.

Ghiglione, J.-F., G. Mevel, M. Pujo-Pay, L. Mousseau, P. Lebaron, and M. Goutx (2007), Diel and seasonal variations in abundance, activity, and community structure of particle-attached and free-living bacteria in NW Mediterranean Sea, Microbial Ecol., 54, 217-231.

Herrmann, M. (2007), Formation et devenir des masses d'eau en Méditerranée Nord-Occidentale, Influence sur l'écosysteme plantonique pélagique, Variabilité interannuelle et changement climatique, $\mathrm{PhD}$ thesis, Univ. Toulouse III Paul Sabatier, Toulouse, France.

Herrmann, M., and S. Somot (2008), Relevance of ERA40 dynamical downscaling for modeling deep convection in the Mediterranean Sea Geophys. Res. Lett., 35, L04607, doi:10.1029/2007GL032442.

Herrmann, M., S. Somot, F. Sevault, C. Estournel, and M. Déqué (2008a), Modeling the deep convection in the Northwestern Mediterranean sea using an eddy-permitting and an eddy-resolving model: Case study of winter 1986-87, J. Geophys. Res., 113, C04011, doi:10.1029/ 2006JC003991.

Herrmann, M., C. Estournel, M. Déqué, P. Marsaleix, F. Sevault, and S Somot (2008b), Dense water formation in the Gulf of Lions shelf: Impact of atmospheric interannual variability and climate change, Cont. Shelf Res., 28(15), 2092-2112, doi:10.1016/j.csr.2008.03.003.

Herrmann, M., J. Bouffard, and K. Béranger (2009), Monitoring openocean deep convection from space, Geophys. Res. Lett., 36, L03606, doi:10.1029/2008GL036422.

Herrmann, M., F. Sevault, J. Beuvier, and S. Somot (2010), What induced the exceptional 2005 convection event in the northwestern Mediterranean basin? Answers from a modeling study, J. Geophys. Res., 115, C08029, doi: 10.1029/2009JC005749.

IPCC (2001), Climate Change 2011, in The Scientific Basis. Contribution of Working Group I to the Third Assessment Report of the IPCC, edited by J. H. Houghton et al., 881 pp., Cambridge Univ. Press, Cambridge, U. K.

Körtzinger, A., U. Send, R. S. Lampitt, S. Hartman, D. W. R. Wallace, J. Karstensen, M. G. Villagarcia, O. Llinas, and M. D. DeGrandpre (2008), The seasonal pco2 cycle at $49.8 \mathrm{n} / 16.58 \mathrm{w}$ in the northeastern Atlantic ocean and what it tells us about biological productivity, J. Geophys Res., 113, C04020, doi:10.1029/2007JC004347.

Kouwenberg, J. (1998), Shift in copepod populations and long-term changes in the Northwestern Mediterranean. An overview, in Final Rep of SCOR/IOC Working Group 93, Pelagic Biogeography, 142, pp. 203-213, Intergovern. Oceanogr. Comm., Paris.

Krom, M., N. Kress, and S. Benner (1991), Phosphorus limitation of primary productivity in the eastern Mediterranean Sea, Limnol. Oceanogr., 36, 424-432.

Lazzari, P., A. Teruzzi, S. Salon, S. Campagna, C. Calonaci, S. Colella, M. Tonani, and A. Crise (2010), Pre-operational short-term forecasts for Mediterranean Sea biogeochemistry, Ocean Sci., 6(1), 25-39, doi: 10.5194/os-6-25-2010.

Lazzari, P., C. Solidoro, V. Ibello, S. Salon, A. Teruzzi, K. Béranger, S Colella, and A. Crise (2011), Seasonal and inter-annual variability of plankton chlorophyll and primary production in the Mediterranean Sea: A modelling approach, Biogeosciences, 9, 217-233.

Leblanc, K., B. Quéguiner, N. Garcia, P. Rimmelin, and P. Raimbault (2003), Silicon cycle in the NW Mediterranean Sea: Seasonal study of a coastal oligotrophic site, Oceanol. Acta, 26, 339-355.

Lévy, M., P. Klein, and A.-M. Treguier (2001), Impact of sub-mesoscale physics on production and subduction of phytoplantkon in an oligotrophic regime, J. Mar. Res., 59, 535-565.

Madec, G., M. Chartier, P. Delecluse, and M. Crépon (1991), A threedimensional numerical study of deep-water formation in the Northwestern Mediterranean Sea, J. Phys. Oceanogr., 21(9), 1349-1371.

Magagnini, M., C. Corinaldesi, L. Monticelli, E. D. Domenico, and R. Danovaro (2007), Viral abundance and distribution in mesopelagic and bathymetric waters of the Mediterranean Sea, Deep Sea Res., Part I, 54(8), 1209-1220.

Mann, K. H., and J. R. N. Lazier (1991), Dynamics of Marine Ecosystem, 466 pp., Blackwell Sci. Publ. Inc., Boston.

Marsaleix, P., F. Auclair, and C. Estournel (2006), Considerations on open boundary conditions for regional and coastal ocean models, Atmos. Oceanic Technol., 23, 1603-1613, doi:10.1175/JTECH1930.1.

Marsaleix, P., F. Auclair, and C. Estournel (2009), Low-order pressure gradient schemes in sigma coordinate models: The seamount test revisited, Ocean Modell., 30, 169-177, doi:10.1016/j.ocemod.2009.06.011.
Marsaleix, P., F. Auclair, C. Estournel, C. Nguyen, and C. Ulses (2011), An accurate implementation of the compressibility terms in the equation of state in a low order pressure gradient scheme for sigma coordinate ocean models, Ocean Modell., 40, 1-13, doi:10.1016/j.ocemod.2011.07.004.

Marsaleix, P., F. Auclair, C. Estournel, C. Nguyen, and C. Ulses (2012), Alternatives to the Robert-Asselin filter, Ocean Modell., 41, 53-66, doi: 10.1016/j.ocemod.2011.11.002

Martin-Cuadrado, A., P. Lopez-Garcia, J.-C. Alba, D. Moreira, L. Monticelli, A. Strittmatter, G. Gottschalk, and F. Rodriguez-Valera (2007), Metagenomics of the deep Mediterranean, a warm bathypelagic habitat, PlosOne, 2(9), e914, doi:10.1371/journal.pone.0000914.

Marty, J.-C., and J. Chiaverini (2002), Seasonal and interannual variations in phytoplankton production at DYFAMED time-series station, northwestern Mediterranean sea, Deep Sea Res., Part II, 49(11), 2017-2030.

Marty, J.-C., and J. Chiaverini (2010), Hydrological changes in the Ligurian Sea (NW Mediterranean, DYFAMED site) during 19952007 and biogeochemical consequences, Biogeosciences, 7, 2117-2128, doi: 10.5194/bg-7-2117-2010.

Marty, J.-C., E. Nicolas, J. Miquel, and S. W. Fowler (1994), Particulate fluxes of organic compounds and their relationship to zooplankton fecal pellets in the northwestern Mediterranean Sea, Mar. Chem., 46, 387405.

Marty, J.-C., J. Chiaverini, M.-D. Pizay, and B. Avril (2002), Seasonal and interannual dynamics of nutrients and phytoplankton pigments in the western Mediterranean Sea at the DYFAMED time-series station (19911999), Deep Sea Res., Part II, 49, 1965-1985.

Mc Gill, D. (1969), A budget for dissolved nutrients salts in the Mediterranean Sea, Cah. Océanogr., 21, 543-554.

MEDOC-Group (1970), Observations of formation of deep-water in the Mediterranean Sea, Nature, 227, 1037-1040.

Mével, G., M. Vernet, M. Goutx, and J.-F. Ghiglione (2008), Seasonal to hour variation scales in abundance and production of total and particleattached bacteria in the open NW Mediterranean sea $(0-1000 \mathrm{~m})$, Biogeosciences, 5, 1573-1586.

Miquel, J., S. Fowler, and J. L. Rosa (1992), Vertical particulate carbon fluxes in the Ligurian sea: A time-series study, Rapport et Procès Verbaux Commission Internationale pour l'Exploration Scientifique de la Mer Mediterranée, Monaco, pp. 33-78.

Molinero, J., F. Ibanez, S. Souissi, E. Buecher, S. Dallot, and P. Nival (2008), Climate control on the long-term anomalous changes of zooplankton communities in the northwestern Mediterranean, Global Change Biol., 14, 11-26.

Moutin, T., T. Thingstad, F. V. Wambeke, F. Marie, G. Slawyk, P. Raimbault, and H. Claustre (2002), Does competition for nanomolar phosphate supply explain the predominance of the cyanobacterium Synechococcus?, Limnol. Oceanogr. Methods, 47(5), 1562-1567.

Moutin, T., F. V. Wambeke, and L. Prieur (2012), Introduction to the Biogeochemistry from the Oligotrophic to the Ultraoligotrophic Mediterranean (BOUM) experiment, Biogeosci. Discuss., 9, 3817-3825.

Niewiadomska, K., H. Claustre, L. Prieur, and F. D’Ortenzio (2008), Submesoscale physical-biogeochemical coupling across the Ligurian Current (northwestern Mediterranean) using a bio-optical glider, Limnol. Oceanogr. Methods, 53(5), 2210-2225.

Nowaczyk, A., F. Carlotti, D. Thibault-Botha, and M. Pagano (2011), Metazooplankton diversity, community structure and spatial distribution across the Mediterranean Sea in summer: Evidence of ecoregions, Biogeosci. Discuss., 8, 3081-3119.

Pinardi, N., M. Zavatarelli, E. Arneri, A. Crise, and M. Ravaioli (2006), The physical, sedimentary and ecological structure and variability of shelf areas in the Mediterranean Sea, in The Sea, vol. 14b, edited by A. R. Robinson and K. Brink, pp. 1243-1330, Harvard Univ. Press, Cambridge, Mass.

Pujo-Pay, M., and P. Conan (2003), Seasonal variability and export of dissolved organic nitrogen in the Northwestern Mediterranean Sea, J. Geophys. Res., 108(C6), 3188, doi:10.1029/2000JC000368.

Pujo-Pay, M., P. Conan, L. Oriol, V. Cornet-Barthaux, C. Falco, J.-F. Ghiglione, C. Goyet, T. Moutin, and L. Prieur (2011), Integrated survey of elemental stoichiometry $(\mathrm{C}, \mathrm{N}, \mathrm{P})$ from the western to eastern Mediterranean Sea, Biogeosci. Discuss., 8, 883-899.

Putt, M., and D. Stoecker (1989), An experimentally determined carbon: Volume ratio for marine "oligotrichous" ciliates from estuarine and coastal waters, Limnol. Oceanogr., 34, 1097-1103.

Raick, C., E. J. M. Delhez, K. Soetaert, and M. Grégoire (2005), Study of the seasonal cycle of the biogeochemical processes in the Ligurian Sea using a 1D, J. Mar. Syst., 55, 177-203. 
Razouls, C., and S. Razouls (1976), Dimensions, poids sec, valeur calorifique et courbes de croissance de deux populations naturelles de coppódes planctoniques en Méditerranée, Vie et Mileu, 26B, 281-297.

Redfield, A. C., B. H. Ketchum, and F. A. Richards (1963), The influence of organisms on the composition of sea water, in The Sea, edited by M. N. Hill, pp. 26-77, Interscience, New York.

Santinelli, C., L. Nannicini, and A. Seritti (2012), DOC dynamics in the meso and bathypelagic layers of the Mediterranean Sea, Deep Sea Res. Part II, 57(16), 1446-1459, doi:10.1016/j.dsr2.2010.02.014.

Sarmiento, J. L., T. Herbert, and J. Toggweiler (1988), Mediterranean nutrient balance and episode of anoxia, Global Biogeochem. Cycles, 2(4), 427-444.

Segura-Noguera, M., A. Cruzado, and D. Blasco (2011), Nutrient preservation, analysis precision and quality control of an oceanographic database of inorganic nutrients, dissolved oxygen and chlorophyll a from the NW Mediterranean Sea, Sci. Mar., 75(2), 321-339.

Sempéré, R., B. Charriere, F. V. Wambeke, and G. Cauwet (2000), Carbon inputs of the Rhône River to the Mediterranean Sea: Biogeochemical implications, Global Biogeochem. Cycles, 14(2), 669-681.

Smith, S., and J. Hollibaugh (1993), Coastal metabolism and the oceanic organic carbon balance, Rev. Geophys., 31(1), 75-89.

Somot, S., F. Sevault, and M. Déqué (2006), Transient climate change scenario simulation of the Mediterranean Sea for the 21 st century using a high resolution ocean circulation model, Clim. Dyn., 27, 1-29, doi: 10.1007/s00382-006-0167-z.

Tanaka, T., and F. Rassoulzadegan (2002), Full-depth profiles (0-2000 m) of bacteria, heterotrophic nanoflagellates and ciliates in the nw Mediterranean sea: Vertical partitioning of microbial trophic structures, Deep Sea Res., Part II, 49, 2093-2107.

Tanaka, T., F. Rassoulzadegan, and T. Thingstad (2003), Measurements of phosphate affinity constants and phosphorus release rates from the microbial food web in Villefranche Bay, northwestern Mediterranean, Limnol. Oceanogr. Methods, 48(3), 1150-1160.
Thingstad, T., and F. Rassoulzadegan (1995), Nutrient limitations, microbial food webs, and 'biological C-pump': Suggested interactions in a P-limited Mediterranean, Mar. Ecol. Prog. Ser., 117, 299-306.

Thingstad, T., and F. Rassoulzadegan (1999), Conceptual models for the biogeochemical role of the photic zone microbial food web, with particular reference to the Mediterranean Sea, Prog. Oceanogr., 44, 271286.

Thingstad, T., U. Zweifel, and F. Rassoulzadegan (1998), P limitation of heterotrophic bacteria and phytoplankton in the northwest Mediterranean, Limnol. Oceanogr., 43(1), 88-94.

Townsend, D. W., M. D. Keller, M. Sieracki, and S. G. Ackleson. (1992), Spring phytoplankton blooms in the absence of vertical water column stratification, Nature, 360, 59-62.

Ulses, C., C. Estournel, P. Puig, X. Durrieu de Madron, and P. Marsaleix (2008), Dense shelf water cascading in the northwestern Mediterranean during the cold winter 2005. Quantification of the export through the Gulf of Lion and the Catalan margin, Geophys. Res. Lett., 35, L07610, doi: 10.1029/2008GL033257.

Vandromme, P., L. Stemman, L. Berline, S. Gasparini, L. Mousseau, F. Prejger, O. Passafiume, J.-M. Guarini, and G. Gorsky (2011), Inter-annual fluctuations of zooplankton communities in the Bay of Villefranche-sur-mer from 1995 to 2005 (Northern Ligurian Sea, France), Biogeosciences, 8, 3143-3158.

Vichi, M., N. Pinardi, and S. Masina. (2007), A generalized model of pelagic biogeochemistry for the global ocean ecosystem. Part I: Theory, J. Mar. Syst., 64, 89-109.

Vidussi, F., J.-C. Marty, and J. Chiaverini (2000), Phytoplankton pigment variations during the transition from spring bloom to oligotrophy in the northwestern Mediterranean sea, Deep Sea Res., Part I, 47, 423-445.

Vörösmarty, C., B. Fekete, and B. Tucker (1996), Global River Discharge Database, RivDis, Int. Hydrol. Program, Global Hydrol. Arch. and Anal Syst., United Nations Educational, Scientific and Cultural Organization (UNESCO), Paris. 